WSRC-RP-91-1227, Rev 0

Keywords: glass, glass durability, crystallization, Product

Consistency Test (PCT)

\title{
DURABILITY OF GLASSES FROM PACIFIC NORTHWEST LABORATORY COMPOSITIONAL VARIABILITY STUDY-II (CVS-II) (U)
}

\section{CAROL M. JANTZEN}

WSRC-RP- $-91-1227$

DE92 018536

\section{Approved by}

E.W. Holtzscheiter, Research Manager

Defense Waste Processing Technology

Publication Date: May 10, 1992

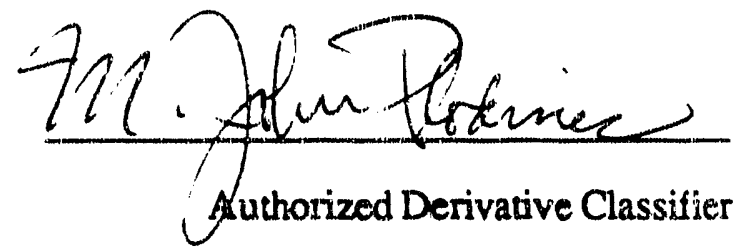

Westinghouse Savannah River Co. Savannah River Site Aiken, SC 29808 
This page intentionally left blank.

$-2$. 


\section{ABSTRACT}

Pacific Northwest Laboratory (PNL) is developing a borosilicate glass as a solid, stable nedium for the disposal of high-level radioactive waste at the Hanford site. They are optimizing the glass forming region and developing process models to be used in the Hanford Waste Vitrification Project (HWVP). Their experimentally-based statistical approach for optimizing the glass composition for HWVP has been designated the Composition Variability Study (CVS).

In Part I of the CVS study PNL tested wide ranges of composition, developed first-order empirical models, and provided input for planning CVS-II. In part II, they are generating glass property data for a number of compositions in order to develop second-order empirical models which will be used to identify the composition region that simultaneously satisfies all quality and processability requirements of HWVP.

Westinghouse Savannah River Company (WSRC) was requested to assist in the CVS-II study by verifying the glass durability properties. The durability of five glasses plus a standard glass was exarnined using the Product Consistency Test (PCT) developed at WSRC for DWPF and using the monolithic durability test developed by the Materials Characterization Center (MCC-1). The data were examined for internal consistency and analytic bias. The raw analytic data are tabulated. The PCT durability is expressed as grams of glass ( $\mathrm{Na}, \mathrm{B}, \mathrm{Li}, \mathrm{Si}$, and $\mathrm{K}$ ) dissolved per liter of leachate $(\mathrm{g} / \mathrm{L})$ and as grams of glass dissolved per square meter $\left(\mathrm{m}^{2}\right)$ of glass surface area exposed $\left(\mathrm{g} / \mathrm{m}^{2}\right)$. The MCC-1 durability is expressed as grams of glass in the leachate per square meter of glass surface area exposed $\left(\mathrm{g} / \mathrm{m}^{2}\right)$. The total chemical analyses of the glasses and the crystalline phases identified are reported. 
This page intentionally left blank.

$-4$. 


\section{Table of Contenis}

Page

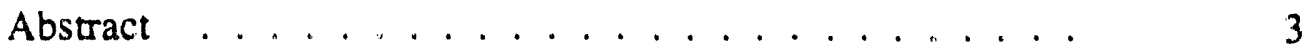

Introduction $\ldots \ldots \ldots \ldots \ldots \ldots \ldots \ldots$

Experimental ................... 8

Quality Assurance . . . . . . . . . . . . . . . . 9

Results and Discussion . . . . . . . . . . . . . . 9

PCT Analyses

Multielement Standard Analyses . . . . . . . . . . $\quad 9$

Standard Glass Analysis . . . . . . . . . . . . . . 9

CVS-II Glass Analysis. . . . . . . . . . . . . . . 9

MCC-1 Arialyses

Multielement Standard Analyses _. . . . . . . . . . 17

Standard Glass Analysis . . . . . . . . . . . . 17

CVS-II Glass Analysis. . . . . . . . . . . . . . . 17

Target Glass Compositions . . . . . . . . . . . . . . 17

X-ray Analyses and Scanning Electron Microscopy . . . . . . 21

Conclusions ..................... 21

References .................. 23

Appendix I : Task Control Matrix ... . . . . . . . 25

Appendix II: Target and Analyzed Glass Compositions . . . . . 27 
This page intentionally left blank.

$-6$. 


\section{DURABILITY OF GLASSES FROM PACIFIC NORTHWEST LABORATORY COMPOSLTIONAL YARIABULTY STUDY.II (U)}

\section{INTRODUCTION}

Waste form producers at the Savannah River Site (SRS), West Valley Nuclear Fuel Services (WVNFS), and Hanford Waste Vitrification Project (HWVP) will immobilize high-level radioactive liquid waste in borosilicate glass. The glass will be poured into stainless steel canisters for eventual disposal in a geologic repository. The Department of Energy has defined a set of requirements for the canistered waste form which must be met in order to assure compatibility with, and acceptance by, the repository. These requirements are the Waste Acceptance Preliminary Specifications (WAPS). 1

The current Waste Acceptance Preliminary Specification (WAPS) 1.3 requires the waste form producers to dernonstrate control of the consistency of the final waste form using the Product Consistency Test. ${ }^{2-3}$ The PCT is a crushed glass durability test which is (1) sensitive to glass composition and homogeneity, and (2) may have the potential to be related to repository sitespecific release tests. It is a glass dominated production test which rapidly and reliably can be used to test glasses during production, even in the remote environments necessitaica by highly radioactive glasses. ${ }^{4-6}$ Therefore, the PCT has been substituted for the MCC-1 test in the current WAPS 1.3 specification. The acceptance criterion for a production glass has been changed to a glass production criterion: the glass being tested during production must have a release which is better than the 131 Stage 2 glass that was qualified in the DWPF Environmental Assessment (EA). 7

Pacific Northwest Laboratory (PNL) is generating glass property data for a number of glass compositions in order to develop process/product models which will be used to identify the composition region that simultaneously satisfies all durability and processability requirements for HWVP. This includes PCT testing and adherence to the current version of the WAPS. The Savannah River Laboratory (SRL) of Westinghouse Savannah River Company (WSRC) was requested to assist PNL by verifying the glass durability properties of the HWVP glasses by testing with both the Product Consistency Test (PCT) and the monolithic MCC-1 test.

This study reports the durability of five glasses designed for HWVP by PNL. These five glasses are part of the PNL's Composition Variability Study - Part II. The contract deliverables include the following:

- leachate concentration data file printout

- leachate conversion/calculation printout

- leachate concentration summary sheet and pH values 


\section{EXPERIMEN'TAL}

The durability of the five glasses from CVS-II were examined using Version 3.0 of the $\mathrm{PCT}^{3}$ (PCT-GTOP-3-025, Rev.0, see Appendix 1). In the PCT analysis crushed glass of 100-200 mesh is immersed in ASTM Type I water for 7 days at $90^{\circ} \mathrm{C}$. The surface area of the glass exposed in $100-200$ mesh glass can be calculated using an assumed waste glass density $(\sim 2.76 \mathrm{~g} / \mathrm{cc}$ for average SRS glasses) and by assuming a Gaussian distribution of particle sizes. Since the volume of leachant solution (V) is maintained at $10 \mathrm{~mL}$ per gram of glass the ratio of the glass surface area (SA) to the volume (V) of leachant is $19.55 \mathrm{~cm}^{-1}$. PCT leachates were filtered to remove colloids and/or particulates. The leachates were analyzed for $\mathrm{pH}$ and the elemental concentration of the glass species of interest.

A standard glass, ARM-1 was used to ascertain if long term bias in the experimental analysis and in the analytical data of these glasses had occurred compared to previous glasses tested at SRS. Triplicate analyses and triplicate glass standards were run simultaneously.

A multielernent solution standard was used to ensure that instrumental drift in the Inductively Coupled Plasma (ICP) Spectroscopy and/or Atomic Absorption (AA) analyses did not significantly bias the short term leachate analyses. Durability tests containing ASTM Type I water but no glass samples were run simultaneously as "blanks." The use of blanks ensure that test vessel preparation was adequate and that the sample leachates can be corrected for elemental variation occurring independently of the glass-solution interactions.

The durability of the five glasses from CVS-II were also examined using PNL's MCC-1P, Rev. 1.0 (PSL-417-LCH, Rev.0, see Appendix 1). In the MCC-1 analysis a monolith of glass is irnmersed in ASTM Type I water for 28 days at $90^{\circ} \mathrm{C}$. The ratio of the specimen surface area (SA) in $\mathrm{m}^{2}$ to volume of solution $(\mathrm{V})$ used was in $\mathrm{m}^{3}$ was the recommended $0.1 \mathrm{~cm}^{-1}$. The leachates were analyzed for $\mathrm{pH}$ and the elemental concentration of the glass species of interest. A standard glass, ARM-1 was also analyzed. Duplicate analyses and duplicate glass standards were run simultaneously. Durability tests containing ASTM Type I water but no glass samples were run simultaneously as "blanks." The use of blanks ensure that test vessel preparation was adequate and that the sample leachates can be corrected for elemental variation occurring independently of the glass-solution interactions.

The target compositions of the five glasses, in oxide wt\%, were provided by G. F. Piepel of PNL. Although not a contract deliverable, portions of the glasses were dissolved and analyzed using DWPF analysis methods ${ }^{8}$ in order to verify the target compositions. A standard glass was dissolved and analyzed simultaneously to ensure that instrumental bias in the analytic equipment could adequately be evaluated. After these analyses were completed, P. Hrma of PNL noted that two of the CVS-II glasses supplied tn SRS (CVS-II-16 and 18) had the composition of the PNL Internal Standard glass and may have been erroneously labeled before being shipped.

$X$-ray diffraction (XRD) and Scanning Electron Microscopy (SEM) analyses coupled with Energy Dispersive Analysis by X-ray (EDAX) were performed on the CVS-II glasses in order to deternine the crystallinity and/or homogeneity of the five glasses and the chermical composition of 
the crystalline phases. These analyses were also not contract deliverables but were included because of the large impact that crystallinity or inhornogeneity can have on glass durability.

\section{QUALITY ASSURANCE}

The PCT Version 3.0 is a Glass Technology Category 1 Procedure requiring experimenter data input and signoff at every step (GTOP-3-025 in The Glass Technology Procedures Manual, DPSTM-88-700-5, L 13-1). All the ovens, balances, and water purification systems used for the PCT and the MCC-1 testing are M\&TE Catcgory 1. The SRL Glass Technology Task Control Matrix is given in Appendix I. All tasks were carried out in accordance with OGR-14 and NQA-1.

Analytic Development Services (SRL/ADS) procedures were followed for all chemical, X-ray and SEM/EDAX analyses. All the data for this study are recorded in DPSTN-4507 (E-48203) on pages 126-153 and in WSRC-NB-90-271 on pages 64 to 111.

\section{RESULTS AND DISCUSSION}

\section{PCT ANALYSES}

\section{Multielement Standard Analysis}

During PCT analysis, a multielement solution standard was used to ensure that instrumental drift did not significantly bias the short term analysis of the leachates. The multielement solution standard was run before leachate analysis began and after every 5 leachate samples (Appendix II). Analysis of the solution standard data indicated that there was less than $0.5 \mathrm{ppm}$ bias in the ICP analyses for $\mathrm{Na}, \mathrm{Li}, \mathrm{Al}, \mathrm{Fe}$, and $\mathrm{Si}$ and less than $0.6 \mathrm{ppm}$ bias in the Atomic Absorption (AA) analyses for $\mathrm{K}$ The data also indicated that there was about a 2 ppm "low" bias in the Na determinations made by AA compared to the $\mathrm{Na}$ determinations by ICP analysis (Table 1).

\section{Standard Glass Analysis}

Historical control charting using PNL's Approved Reference Material (ARM-1) as the standard glass as the PCT standard glass did not indicate any significant bias in the elemental releases (in ppm) for all elements since May 1989. All the standard glass elemental releases used in this study fell within one-sigma of the average elemental release for ARM-1 glass since May, 1989. Hence, no long term bias corrections were made to the CVS-II data set.

\section{CVS-II Glass Analysis}

The leachate concentrations are reported as normalized elemental concentrations, $\mathrm{NC}_{\mathrm{i}}$, released from the glass in grams of glass per $\mathrm{L}$ of leachant and as $\mathrm{NL}_{\mathrm{i}}$, the normalized elemental mass losses released from the glass in grams of glass per $L$ of leachant and per glass surface area exposed. In both cases the leachate concentrations for a given element are normalized by the 


\section{Table 1 Multielement Solution Standard Analysis}

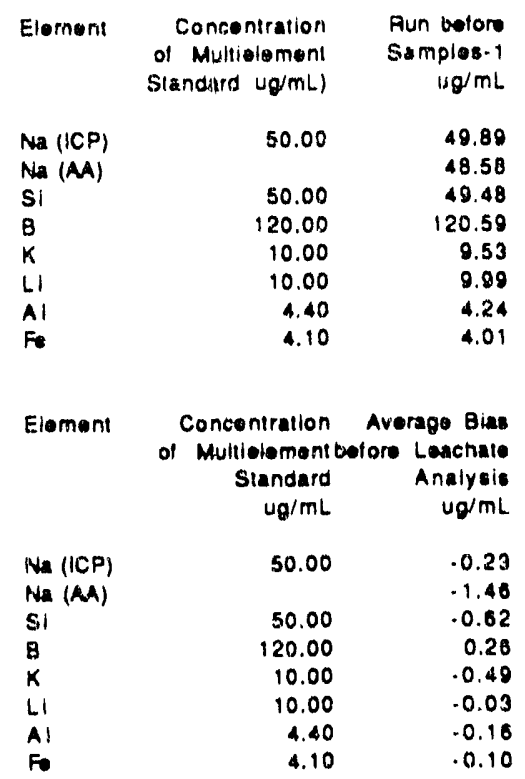

\begin{tabular}{|c|c|c|c|c|c|c|}
\hline $\begin{array}{r}\text { Aun betore } \\
\text { Samples.2 } \\
\text { ug/miL }\end{array}$ & $\begin{array}{r}\text { Run atter } 5 \\
\text { Samples-1 } \\
\text { ug } / \mathrm{mL}\end{array}$ & $\begin{array}{r}\text { Hun sites } 5 \\
\text { Samples-2 } \\
\text { ug/mL }\end{array}$ & $\begin{array}{r}\text { Run otter } 10 \\
\text { Samplos-1 } \\
\text { ugiml }\end{array}$ & $\begin{array}{r}\text { Pun atter } 10 \\
\text { Sampies-2 } \\
\text { ug/mL }\end{array}$ & $\begin{array}{r}\text { Aun atior is } \\
\text { Samplos-1 } \\
u g / m L\end{array}$ & $\begin{array}{r}\text { Aun wher is } \\
\text { Samples-? } \\
\text { vo/mL }\end{array}$ \\
\hline 49.65 & 50.01 & 50.22 & 50.41 & 50.10 & 50.66 & 50.20 \\
\hline 48.51 & 48.35 & 49.01 & 48.35 & 46.20 & 50.00 & 47.35 \\
\hline 49.28 & 50.00 & 49.93 & 50.42 & 49.78 & 50.62 & 50.30 \\
\hline 119.83 & 120.52 & 121.00 & 121.08 & 120.27 & 122.43 & 122.10 \\
\hline 0.49 & 9.41 & 0.40 & 9.30 & 0.23 & 9.41 & 0.39 \\
\hline 9.98 & 10.13 & 10.05 & 10.08 & 10.04 & 10.12 & 10.07 \\
\hline 4.25 & 4.27 & 4.28 & 4.37 & 4.34 & 4.23 & 4.20 \\
\hline 4.00 & 4.01 & 4.04 & 4.08 & 4.04 & 4.08 & 4.04 \\
\hline
\end{tabular}

\section{ELEMENT TOTAL AVEAACE \\ BilaS}

ug/mi

$\begin{array}{lr}\text { Ne (KCP) } & 0.15 \\ \text { Ha (AA) } & -1.71 \\ \text { SI } & 0.00 \\ \text { B } & 0.09 \\ \text { K } & -0.50 \\ \text { LI } & 0.05 \\ \text { Al } & -0.13 \\ \text { Fe } & 0.07\end{array}$

Average Biss

Averape Blas ather 10 Lenchate Anslyeos

ug/mL

0.11

.1 .32

.0 .01

0.76

.0 .55

0.09

$-0.12$

.0 .07

0.30

.2 .73

0.10

0.80

.0 .74

0.00

.0 .04

15 Leachote

Anulyses

0.41

$-1.32$

0.51

2.27

.0 .00

0.08

$-0.18$

.0 .06 
weight fraction of that element in the glass. The normalized mass loss, $\mathrm{NL}_{\mathrm{i}}$, is a function of (1) the mass fraction of that element in the glass, (2) the exposed surface area of the glass, and (3) the leachate volume, as given below:

$$
N L_{i}=\frac{C_{i}}{F_{i}(S A / V)}
$$

where

$$
\begin{aligned}
N_{L_{i}}= & \text { normalized elemental mass loss }\left(g_{\text {glass }} / \mathrm{m}^{2}\right) \\
C_{i}= & \text { mass of element " } \mathrm{i} \text { " in the solution corrected for the average mass } \\
& \text { of element " } \mathrm{i} \text { " in the blanks }\left(\mathrm{g}_{\mathrm{i}} / \mathrm{m}^{3}\right) \\
\mathrm{F}_{\mathrm{i}}= & \text { fraction of element " } \mathrm{i} \text { " in the glass }\left(\mathrm{g}_{\mathrm{j}} / \mathrm{g}_{\text {glass }}\right) \\
\mathrm{SA}= & \text { specimen surface area }\left(\mathrm{m}^{2}\right) \\
V= & \text { solution volume }\left(\mathrm{m}^{3}\right)
\end{aligned}
$$

Equation 1 provides leachate concentrations in grams of glass per $\mathrm{m}^{2}$ of glass surface area exposed. Since the SA/V term in Equation 1 is constant during PCT analyses the alternative expression given below is used preferentially in this study.

$$
\mathrm{NC}_{\mathrm{i}}=\frac{\mathrm{C}_{\mathrm{i}}}{\mathrm{F}_{\mathrm{i}}}
$$

The units of $\mathrm{NC}_{\mathrm{i}}$ are, therefore, expressed as grams of glass per $\mathrm{L}$ of leachant. The leachate $\mathrm{pH}$ and leachate concentrations, expressed as ppm, $\mathrm{NL}_{\mathrm{i}}$, and $\mathrm{NC}_{\mathrm{i}}$, are given in Table 2 .

Boron and lithium releases from glass are considered to be the most accurate indicators of glass durability since these elements are leached from glass more rapidly than other elements. In addition, boron is considered to be the best indicator of glass durability because boron does not saturate in the leachate and does not participate in precipitation reactions caused by solution supersaturation. Therefore, the elemental releases measured in the leachates were checked for internal consistency by plotting the releases in $\mathrm{ppm}$ for $\mathrm{Li}, \mathrm{Si}, \mathrm{Na}$, and $\mathrm{K}$ against the normalized releases of $\mathrm{B}$ (Figure 1). The plots of $\mathrm{Li}$ and $\mathrm{K}$ versus $\mathrm{B}$ were consistent, e.g. if a given glass released a great deal of B it, likewise, released a great deal of Li or $\mathrm{K}$. The trends for Si versus B and Na versus B are not as consistent because the data for CVS 2-7 appears suspect. Figure 1 also demonstrates the consistently low bias in the $\mathrm{Na}$ analyses by $\mathrm{AA}$ over the $\mathrm{Na}$ analyses by ICP.

The normalized releases were calculated using the analyzed glass compositions given in Table 3 and Appendix III. The normalized releases were calculated in grams of glass (grams of $\mathrm{B}, \mathrm{Li}, \mathrm{Si}$, $\mathrm{Na}$, and $\mathrm{K}$ ) leached per liter of leachate $(\mathrm{g} / \mathrm{L})$ as given in Equations 1 and 2 . The calculation of $\mathrm{NL}_{\mathrm{i}}, \mathrm{NC}_{\mathrm{i}}, \log \mathrm{NL}_{\mathrm{i}}$, and $\log \mathrm{NC}_{\mathrm{i}}$ are given in Tables 4 and 5. 


\section{Table 2. PCT Leachate Concentrations for CVS-II Glasses}

\begin{tabular}{|c|c|c|c|c|c|c|c|c|}
\hline Simpio & $\begin{array}{l}\text { AOS } \\
\text { SAMPLE : }\end{array}$ & $\begin{array}{l}\text { LEACHATE } \\
\text { pH } 1025^{\circ} \mathrm{C}\end{array}$ & $\begin{array}{r}\text { BIN LEACHATE } \\
\text { (PPM) }\end{array}$ & $\begin{array}{r}\text { SIIN LEACHATE } \\
\text { (PPM) }\end{array}$ & $\begin{array}{l}\text { KINLEACMATE } \\
\text { (PPN) }\end{array}$ & $\begin{array}{l}\text { Na IN LEACHATE N } \\
\text { BY ICP (PPW) }\end{array}$ & $\begin{array}{r}\text { Na NLEACHATE } \\
\text { BY AA (PPM) }\end{array}$ & $\begin{array}{r}\text { U IN LEACHATE } \\
\text { (PPM) }\end{array}$ \\
\hline CVS2.5.7.1 & 200059596 & 9.57 & 30.210 & 43.257 & $<0.1$ & 38.780 & 36.592 & 6.363 \\
\hline $\begin{array}{l}\text { CVS2.5.7.2 } \\
\text { CVS2.5.7.3 }\end{array}$ & $\begin{array}{l}200059597 \\
200059598\end{array}$ & $\begin{array}{l}0.57 \\
9.56\end{array}$ & $\begin{array}{l}20.935 \\
30.015\end{array}$ & $\begin{array}{l}43.362 \\
43.998\end{array}$ & $<0.1$ & $\begin{array}{l}38.082 \\
39.695\end{array}$ & $\begin{array}{l}36.261 \\
37.254\end{array}$ & $\begin{array}{l}0.352 \\
6.521\end{array}$ \\
\hline AVERAGE & & 9.57 & 30.363 & 43.539 & 0.1 & 39.052 & 36.702 & 0.412 \\
\hline * STD DEV & & 0.00 & 0.49 & 0.33 & & 0.46 & 0.41 & 0.08 \\
\hline CV52.7.7.1 & 200059588 & 9.77 & $\begin{array}{l}78.042 \\
68.590\end{array}$ & $\begin{array}{l}75.771 \\
73.008\end{array}$ & $\begin{array}{l}<.1 \\
<0.1\end{array}$ & $\begin{array}{l}39.446 \\
34.377\end{array}$ & $\begin{array}{l}39.572 \\
34.274\end{array}$ & $\begin{array}{l}37.574 \\
33.239\end{array}$ \\
\hline $\begin{array}{l}\text { CVS2-7.7.2 } \\
\text { CVS2.7.7.3 }\end{array}$ & $\begin{array}{l}200050580 \\
200050500\end{array}$ & $\begin{array}{l}9.78 \\
9.78\end{array}$ & 72.760 & 73.220 & $<0.1$ & 36.582 & 36.433 & 35.001 \\
\hline AVERAGE & & 9.78 & 73.137 & 74.000 & $<0.1$ & 38.802 & 36.426 & 35.274 \\
\hline \%STD DEV & & 0.00 & 3.66 & 1.26 & & 2.08 & 2.27 & 1.70 \\
\hline CVs2.18-7.1 & 200059591 & 10.24 & 69.067 & 157.380 & 1.610 & 141.130 & 141,030 & 30.932 \\
\hline CVS2.16.7.2 & 200059592 & 10.24 & 71.277 & 158.200 & 1.524 & 143.710 & 137.406 & 31.562 \\
\hline CVS2.16-7.3 & 200059593 & 10.24 & 70.533 & 158.540 & 1.509 & 143.150 & 142.677 & 31.404 \\
\hline $\begin{array}{l}\text { AVERMGE } \\
\text { \% STO DEV }\end{array}$ & & $\begin{array}{r}10.24 \\
0.00\end{array}$ & $\begin{array}{r}70.589 \\
0.58\end{array}$ & $\begin{array}{r}158.040 \\
0.40\end{array}$ & $\begin{array}{r}1.578 \\
0.04\end{array}$ & $\begin{array}{r}142.063 \\
1.11\end{array}$ & $\begin{array}{r}140.371 \\
2.20\end{array}$ & $\begin{array}{r}31.290 \\
0.27\end{array}$ \\
\hline CVS2-17.7.1 & 200059583 & 10.17 & 28.473 & 64.188 & 0.245 & 48.543 & 45.008 & 14.082 \\
\hline CVS2.17.7.2 & 200059584 & 10.17 & 27.338 & 62.504 & 0.250 & 46.700 & 15.884 & 13.538 \\
\hline CVS2.17.7.3 & 200059585 & 10.16 & 27.730 & 63.330 & 0.235 & $\$ 7.260$ & 46.867 & 13.650 \\
\hline AVEPAGE & & 10.17 & 27.860 & 63.337 & 0.245 & 47.504 & 10.140 & 13.753 \\
\hline * STO DEV & & 0.00 & 0.47 & 0.68 & 0.01 & 0.77 & 0.51 & 0.22 \\
\hline CVS.18.7.1 & 200059580 & 10.32 & 100.180 & 187.900 & 1.718 & 197.170 & 190.785 & 42.652 \\
\hline CVS. $18 \cdot 7-2$ & 200050581 & 10.32 & 97.750 & 187.890 & 1.570 & $102.6 n 0$ & 186.502 & 41.805 \\
\hline CVS.18.7.3 & 200059582 & 10.32 & 100.340 & 189.370 & 1.683 & 196.880 & 188.808 & 42.501 \\
\hline AVERAGE & & 10.32 & 98.420 & 188.387 & 1.652 & 105.643 & 188.698 & 42.286 \\
\hline * STD DEV & & 0.00 & 1.18 & 0.70 & 0.08 & 2.09 & 1.75 & 0.34 \\
\hline A $A M \cdot 1.7 .1$ & $200050 r 00$ & 10.42 & 18.006 & 64.860 & 0.213 & 38.230 & 37.254 & 14.883 \\
\hline АคМ.1.7.2 & 200059600 & 10.42 & 19.501 & 64.226 & 0.171 & 39.855 & 39.407 & 15.102 \\
\hline ARM-1.7-3 & 200050601 & 10.42 & 18.128 & 82.053 & 0.213 & 37.751 & 38.095 & 14.302 \\
\hline AVEPUGE & & 10.42 & 18.845 & 63.713 & 0.199 & 38.048 & 37.585 & 14.789 \\
\hline * STD DEV & & 0.00 & 0.56 & 1.20 & 0.02 & 0.88 & 1.37 & 0.35 \\
\hline BLANK-7.1 & 200059804 & 5.92 & $<0.004$ & 0.131 & 0.382 & $<0.010$ & 0.070 & $<0.001$ \\
\hline BLANK-7.2 & 200059605 & 5.83 & $<0.004$ & 0.411 & $\infty .8$ & $<0.010$ & 0.080 & $<0.001$ \\
\hline AVEPUGE & & 6.98 & $<0.004$ & 0.271 & 0.181 & $<0.010$ & 0.085 & $<0.001$ \\
\hline * STU DEV & & 0.05 & & 0.14 & 0.00 & & 0.01 & \\
\hline
\end{tabular}

Notebook WSAC-NB-80-271 

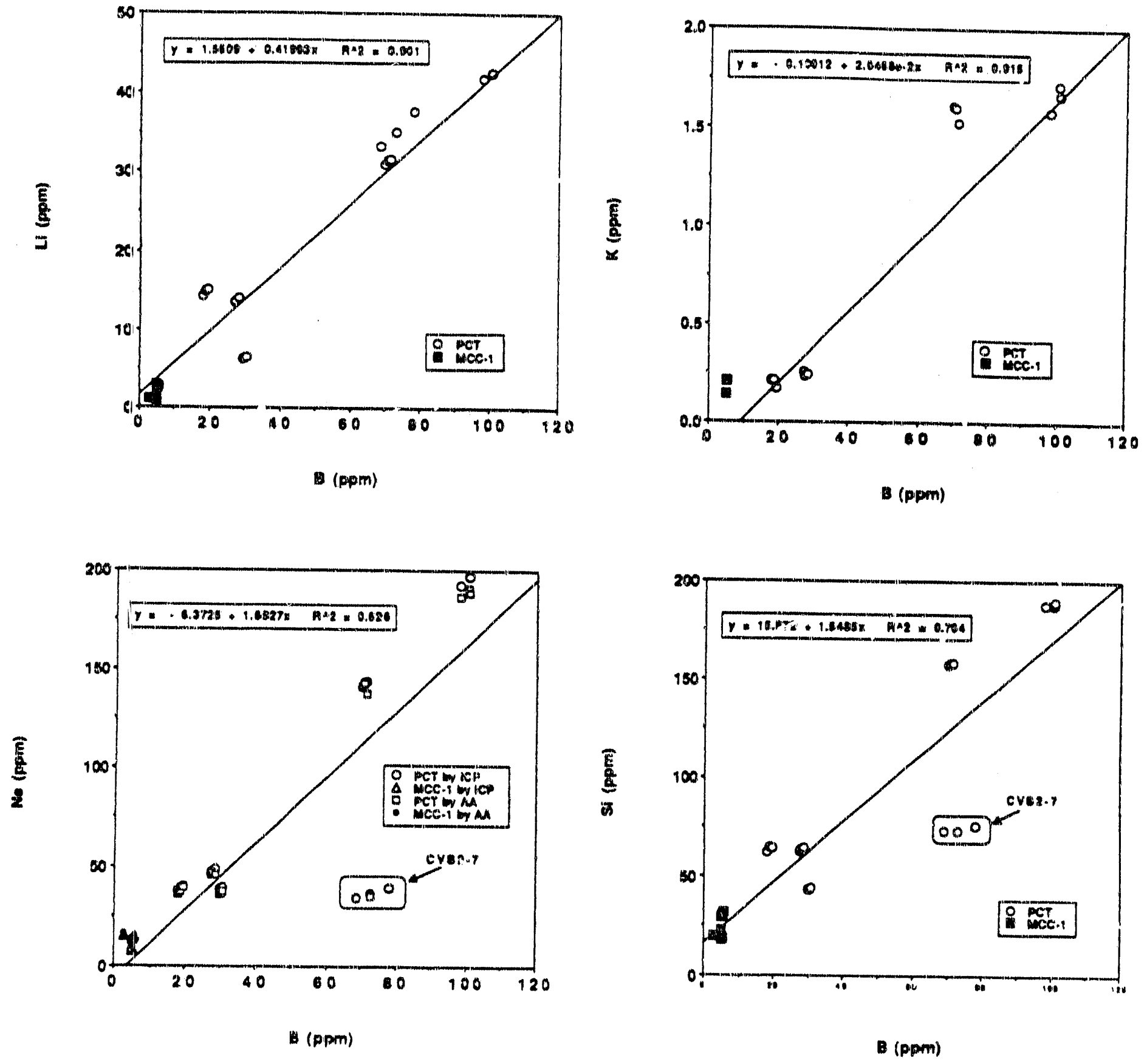

Figure 1. Internal Consistency of PCT and MCC-1 Leachate Data. 
Table 3. Elemental Concentrations of Analyzed CVS-II Glasses (see Appendix II)

\begin{tabular}{|c|c|c|c|c|c|}
\hline Sumplo & $\begin{array}{l}B \text { mox } \\
\text { in gtans }\end{array}$ & $\begin{array}{l}\text { s mps } \\
\text { in olases }\end{array}$ & $\begin{array}{l}x \text { m } \\
\text { In }\end{array}$ & $\begin{array}{l}\text { Ne mox } \\
\text { in olatex }\end{array}$ & if mo \\
\hline $\begin{array}{l}\text { CV } 32 \cdot 5 \cdot 28 \cdot 1 \\
\text { CV } \$ 2 \cdot 5 \cdot 28 \cdot 2 \\
\text { AVERAOE }\end{array}$ & $\begin{array}{l}4.554 \\
4.554 \\
4.654\end{array}$ & $\begin{array}{l}21.010 \\
21.019 \\
21.010\end{array}$ & & $\begin{array}{l}7.770 \\
7.770 \\
7.770\end{array}$ & $\begin{array}{l}0.801 \\
0.801 \\
0.941\end{array}$ \\
\hline $\begin{array}{l}\text { CI.82.7.28-1 } \\
\text { CV } 82 \cdot 7-28.2 \\
\text { AVEAMOE }\end{array}$ & $\begin{array}{l}4.713 \\
4.713 \\
4.713\end{array}$ & $\begin{array}{l}21.810 \\
21.610 \\
21.810\end{array}$ & & $\begin{array}{l}6.075 \\
5.875 \\
6.876\end{array}$ & $\begin{array}{l}2.840 \\
2.648 \\
2.648\end{array}$ \\
\hline $\begin{array}{l}\text { CV82.10.20. } \\
\text { CV } 32.16 .26 . \\
\text { AVERABE }\end{array}$ & $\begin{array}{l}3.332 \\
3.332 \\
3.332\end{array}$ & $\begin{array}{l}22.202 \\
22.202 \\
22.202\end{array}$ & $\begin{array}{l}0.250 \\
0.250 \\
0.250\end{array}$ & $\begin{array}{l}8.185 \\
8.185 \\
6.185\end{array}$ & $\begin{array}{l}1.8 i ? \\
1.580 \\
1.680\end{array}$ \\
\hline $\begin{array}{l}\text { CVSR.17.2 } \\
\text { CVER. } 7.20 . \\
\text { AVERABE }\end{array}$ & $\begin{array}{l}3.140 \\
3.188 \\
9.188\end{array}$ & $\begin{array}{l}20.0871 \\
20.087 \\
20.087\end{array}$ & $\begin{array}{l}0.024 \\
0.024 \\
0.024\end{array}$ & $\begin{array}{l}7.245 \\
7.245 \\
7.246\end{array}$ & $\begin{array}{l}1.742 \\
1.742 \\
1.742\end{array}$ \\
\hline $\begin{array}{l}\text { CV8.19-28.1 } \\
\text { CVE.10.28-2 } \\
\text { AVERMEL }\end{array}$ & $\begin{array}{l}2.010 \\
2.010 \\
2.010\end{array}$ & $\begin{array}{l}22.804 \\
22.604 \\
22.804\end{array}$ & $\begin{array}{l}0.230 \\
0.230 \\
0.230\end{array}$ & $\begin{array}{l}7.000 \\
7.080 \\
7.080\end{array}$ & $\begin{array}{l}1.680 \\
1.868 \\
1.860\end{array}$ \\
\hline $\begin{array}{l}\text { AAM-1.28.1 } \\
\text { AAM-1.28.2 } \\
\text { AVERAOE }\end{array}$ & $\begin{array}{l}3.688 \\
3.868 \\
3.688\end{array}$ & $\begin{array}{l}21.617 \\
21.547 \\
21.847\end{array}$ & & $\begin{array}{l}7.268 \\
7.285 \\
7.286\end{array}$ & $\begin{array}{l}2.380 \\
2.380 \\
2.380\end{array}$ \\
\hline
\end{tabular}




\begin{tabular}{|c|c|c|c|c|c|}
\hline 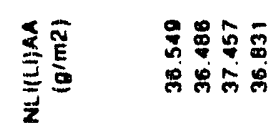 & 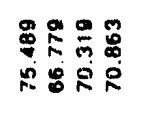 & 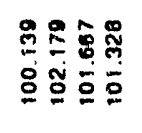 & 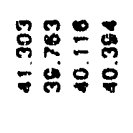 & 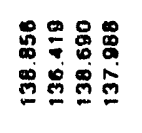 & 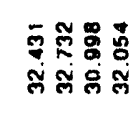 \\
\hline 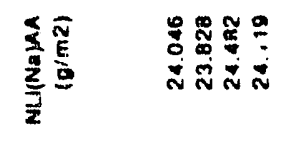 & 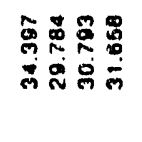 & 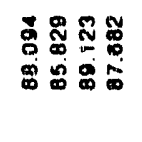 & 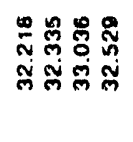 & 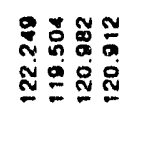 & 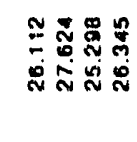 \\
\hline 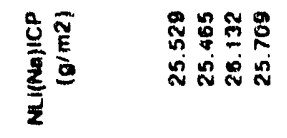 & 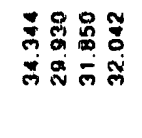 & 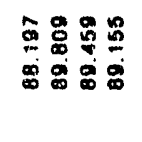 & 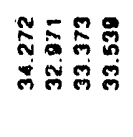 & 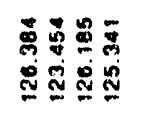 & 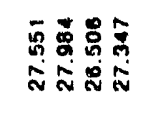 \\
\hline 영영 & 영영영 & 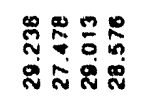 & 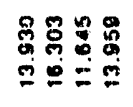 & 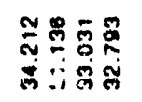 & 영영 \\
\hline
\end{tabular}

这

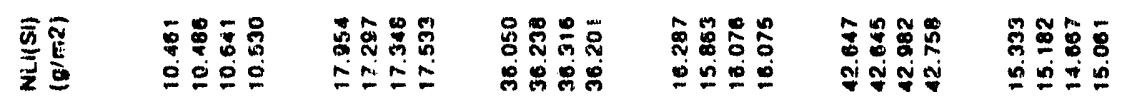

至

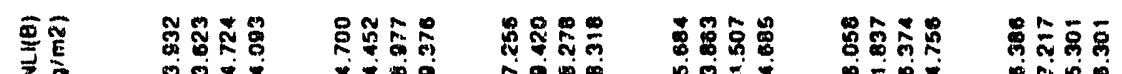

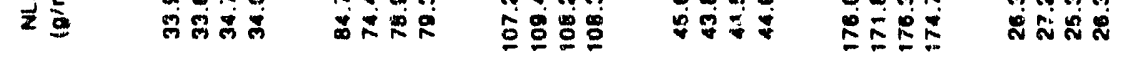

輷

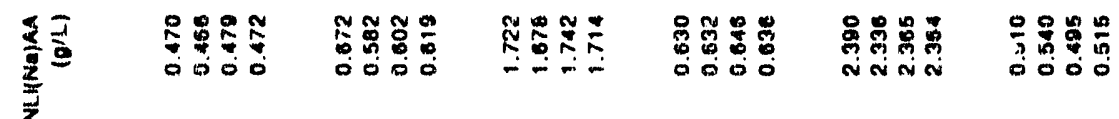

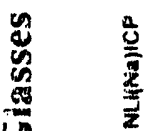

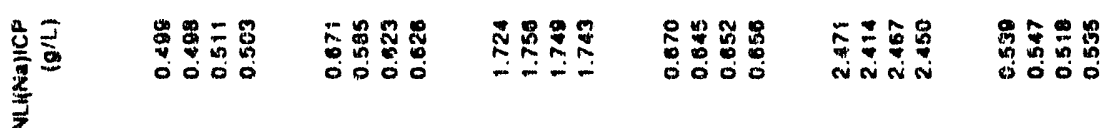

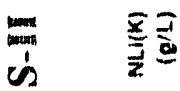

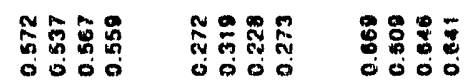

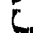

点

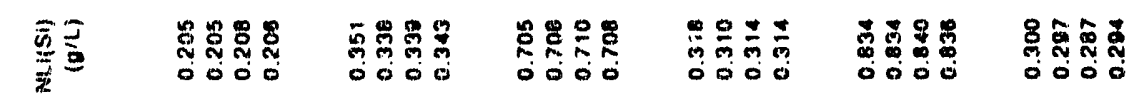

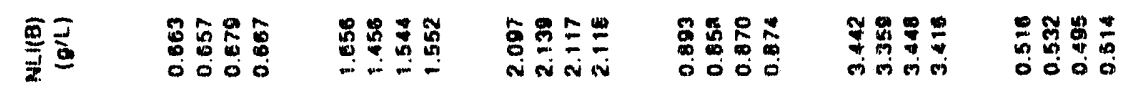

罣

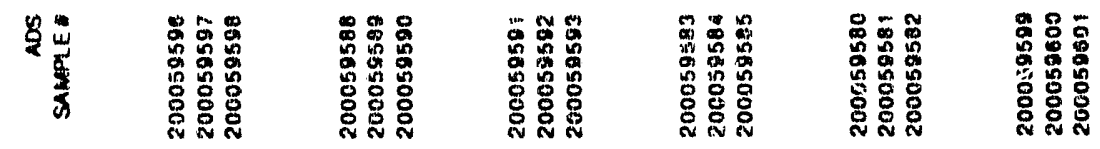

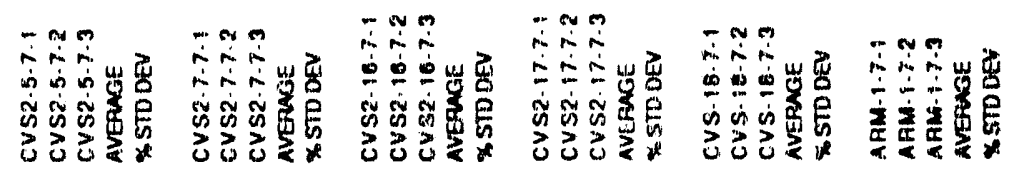




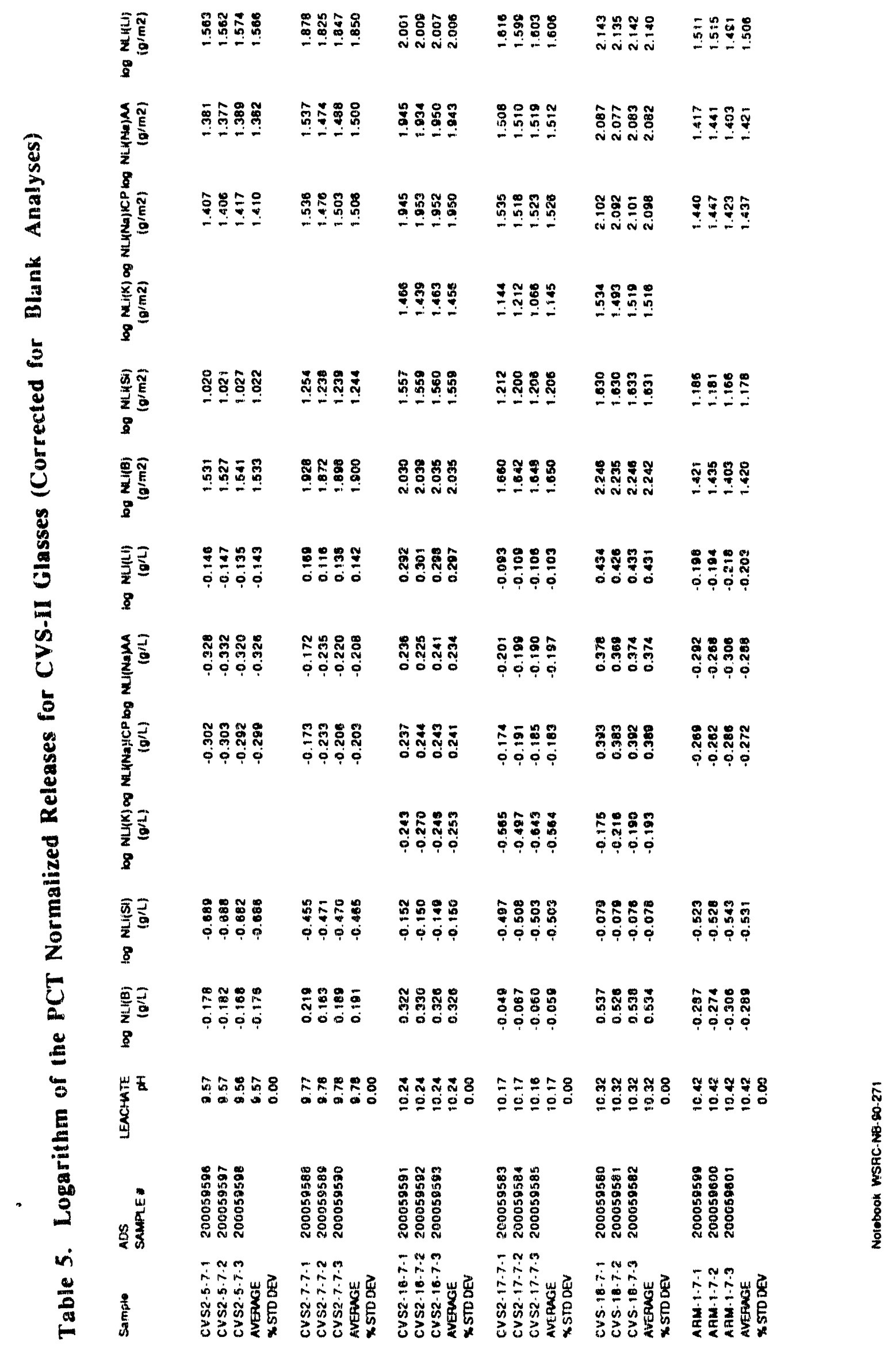




\section{MCC-1_ANALYSES}

\section{Multielement Standard Analysis}

The MCC-1 procedure provided by PNL does not require the use of a multielement standard.

\section{Standard Glass Analysis}

The MCC-1 procedure provided by PNL does not require the use of a standard glass. Although PNL's Approved Reference Material (ARM-1) was leached as a standard glass along with the CVS-II glasses, there was no historical data base for MCC-1 testing with this glass. No statement could be made about the analytic bias. The standard glass analytic results are given in Table 6 .

\section{CVS-II Glass Analysis}

The raw data used to convert the leachate concentrations to $\mathrm{NL}_{\mathrm{i}}$ is given in Table 6 . The elemental releases measured in the leachates were checked for internal consistency by simultaneously plotting the releases in ppm for $\mathrm{Li}, \mathrm{Si}, \mathrm{Na}$, and $\mathrm{K}$ against the normalized releases of $\mathrm{B}$ along with the data from the PCT analysis (Figure 1). The MCC-1 data also shows the consistently low bias in the Na analyses by AA compared to the Na analyses by ICP.

The normalized releases were calculated using the analyzed glass compositions in Table 3 and Appendix II. The normalized releases, $\mathrm{NL}_{\mathrm{i}}$ and $\log \mathrm{NL}_{\mathrm{i}}$, were calculated in grams $\mathrm{B}, \mathrm{Li}, \mathrm{Si}, \mathrm{Na}$, and $\mathrm{K}$ leached per glass surface area exposed $\left(\mathrm{g} / \mathrm{m}^{2}\right)$ as given in Equation 1 (Tables 7 and 8 ).

\section{TARGET GLASS COMPOSICIONS}

The CVS-II glasses were analyzed chemically (Appendix II) in duplicate along with a standard SRS glass from the Waste Compliance Plan, e.g. WCP Purex glass. The analysis included a redox measurement. The analysis did not include analysis of $\mathrm{Ce}, \mathrm{Na}$, and $\mathrm{Y}$. Therefore, the target values for these elements were used and are indicated in bold in the oxide wt\% columns in Appendix II.

Comparison of the analyzed compositions with the target compositions is good except for the presence of minor constituents which were found during chemical analysis. This included $\mathrm{MnO}$, $\mathrm{ZnO}, \mathrm{TiO}_{2}$, and $\mathrm{K}_{2} \mathrm{O}$ as well as $\mathrm{FeO}$ indicated by the redox state measured. The analytic values for $\mathrm{Al}, \mathrm{Si}$, and $\mathrm{B}$ were biased low compared to the standard Purex glass analysis. All three of these analyses are measured from a $\mathrm{Na}_{2} \mathrm{O}_{2}$ dissolution rather than the microwave dissolution used for the remainder of the analysis. Once a $7 \%$ bias correction was applied to the 3 elements from the $\mathrm{Na}_{2} \mathrm{O}_{2}$ dissolution, the analyzed and target values were in excellent agreement (Appendix. II). 
Table 6. MCC-1 Leachate Concentration Data for CVS-II Glasses

\begin{tabular}{|c|c|c|c|c|c|c|c|c|}
\hline Sample & $\begin{array}{l}\text { ADS } \\
\text { SAMPLE }\end{array}$ & $\begin{array}{l}\text { LEACHATE } \\
\text { PH } 25^{\circ} \mathrm{C}\end{array}$ & $\begin{array}{r}\text { BIN LEACHATE } \\
\text { (PPN) }\end{array}$ & $\begin{array}{r}\text { SI IN LEACHATE } \\
\text { (PPMA }\end{array}$ & $\begin{array}{r}\text { KIN LEACHATE } \\
\text { (PPM) }\end{array}$ & $\begin{array}{l}\text { NE WLEACHATE } \\
\text { BY ICP (PPM) }\end{array}$ & $\begin{array}{r}\text { NLLEACHATE } \\
\text { OY M (PPW) }\end{array}$ & $\begin{array}{r}\text { UIN LEACHUTE } \\
\text { (PPM) }\end{array}$ \\
\hline cVS2.5.28.1 & 200082210 & 8.88 & 4.966 & 18.008 & $<0.1$ & 7.668 & 7.480 & 0.921 \\
\hline CVS2.5.28.2 & 200062211 & 0.01 & 5.081 & 18.358 & $<0.1$ & 7.578 & $\begin{array}{r}7.500 \\
.535\end{array}$ & 0.033 \\
\hline $\begin{array}{l}\text { AVERMGE } \\
\text { \% STD DEV }\end{array}$ & & $\begin{array}{l}9.00 \\
0.01\end{array}$ & $\begin{array}{r}5.023 \\
0.08\end{array}$ & $\begin{array}{r}18.183 \\
0.17\end{array}$ & $<0.1$ & $\begin{array}{r}7.023 \\
0.05\end{array}$ & $\begin{array}{l}1.535 \\
0.06\end{array}$ & $\begin{array}{r}0.827 \\
0.01\end{array}$ \\
\hline CVS2.7.28.1 & 200062212 & 8.90 & 2.584 & 19.940 & $<0.1$ & 15.280 & 16.200 & 1.148 \\
\hline $\begin{array}{l}\text { CVS2.7.28.2 } \\
\text { AVERAEE }\end{array}$ & 200062213 & $\begin{array}{l}9.90 \\
9.90\end{array}$ & $\begin{array}{l}2.588 \\
2.583\end{array}$ & $\begin{array}{l}19.586 \\
19.783\end{array}$ & $\begin{array}{l}<0.1 \\
<0.1\end{array}$ & $\begin{array}{l}15.012 \\
15.140\end{array}$ & $\begin{array}{l}15.800 \\
15.800\end{array}$ & $\begin{array}{l}1.126 \\
1.137\end{array}$ \\
\hline K STD DEV & & 0.00 & 0.00 & 0.18 & & 0.14 & 0.30 & 0.01 \\
\hline CVS2.16-28.1 & 200062214 & 9.50 & 5.343 & 30.954 & $<0.1$ & 13.827 & 14.400 & 2.500 \\
\hline CVS2.16.28.2 & 200062215 & 9.50 & 5.571 & 32.058 & $\infty .1$ & 14.513 & 15.210 & 2.713 \\
\hline AVERABE & & 9.55 & 5.467 & 31.507 & $<0.9$ & 14.170 & 14.805 & 2.056 \\
\hline *STD DEV & & 0.05 & 0.11 & $0.5 E$ & & 0.34 & 0.41 & 0.08 \\
\hline CVS2.17.28.1 & 200062216 & 9.45 & 4.800 & 20.333 & $\infty .1$ & 9.812 & 10.370 & 2.252 \\
\hline CVS2.17.28.2 & 200062217 & 0.42 & 4.700 & 20.818 & $<0.1$ & 0.770 & 10.460 & 2.252 \\
\hline AVERAGE & & 0.44 & 4.804 & 20.475 & $\infty 0.1$ & 9.791 & 10.415 & $2.25 \%$ \\
\hline * STODEV & & 0.02 & 0.01 & 0.14 & & 0.02 & 0.08 & 0.00 \\
\hline CVS. 18.28 .1 & 200062218 & 9.50 & 5.002 & 29.288 & 0.143 & 13.064 & 13.930 & 2.433 \\
\hline CVS.18.28.2 & 200062210 & 9.50 & 5.100 & 29.864 & 7.208 & 13.244 & 14.180 & 2.480 \\
\hline AVERAGE & & 9.59 & 5.051 & 29.545 & 0.170 & 13.154 & 14.085 & 2.461 \\
\hline * STD DEV & & 0.00 & 0.06 & 0.30 & 0.03 & 0.00 & 0.13 & 0.03 \\
\hline ARM.1.28.1 & 200062220 & 9.55 & 4.838 & 22.818 & 0.1 & 9.597 & 10.460 & 2.071 \\
\hline AAM-1.28.2 & 200002221 & 9.50 & 4.847 & 22.180 & $\leftarrow 0.1$ & 9.509 & 0.720 & 2.900 \\
\hline AVEPAGE & & 0.53 & 4.8 .43 & 22.404 & $<0.1$ & 9.553 & 10.000 & 2.086 \\
\hline * STO DEV & & 0.02 & 0.00 & 0.21 & & 0.04 & 0.37 & 0.01 \\
\hline BLANK-28-1 & 200062222 & 6.86 & 0.100 & 0.160 & $<0.1$ & 0.186 & 0.108 & $<0.01$ \\
\hline BLANK-26-2 & 200062223 & 6.02 & 0.020 & 0.230 & $<0.1$ & 0.147 & 0.082 & 0.007 \\
\hline AVERAGE & & 6.89 & 0.06 & 0.20 & & 0.16 & 0.00 & 0.00 \\
\hline × STO DEV & & 0.03 & 0.04 & 0.03 & & 0.01 & 0.01 & \\
\hline
\end{tabular}

Nolebook DPSTN-4507 (E40203) 


\section{Table 7. MCC-1 Normalized Releases for CVS-II Glasses (Corrected for Blank Analyses)}

\begin{tabular}{|c|c|c|c|c|c|c|c|c|}
\hline Samplo & AOS & $\begin{array}{r}\text { LEACHATE } \\
\text { WH }\end{array}$ & $\begin{array}{r}N L 1(\theta) \\
(\theta / m 2)\end{array}$ & $\begin{array}{l}N L 1 / S 1) \\
(g / m \mid 2)\end{array}$ & $\begin{array}{l}N \text { LI(K) } \\
(0 / m 2)\end{array}$ & $\begin{array}{r}\text { NLI(Na)ICP } \\
\left(0 / \mathrm{m}^{2}\right)\end{array}$ & $\begin{array}{r}\text { NLKNa)AA } \\
(g / \operatorname{ma} 2)\end{array}$ & $\begin{array}{r}\text { NLIILISAA } \\
(0 / \ln 2)\end{array}$ \\
\hline $\begin{array}{l}\text { CVS2.5.28.1 } \\
\text { CVS2.5.28.2 } \\
\text { AVERGE }\end{array}$ & $\begin{array}{l}200062210 \\
200062211\end{array}$ & $\begin{array}{l}8.98 \\
9.01 \\
9.00\end{array}$ & $\begin{array}{l}10.771 \\
11.025 \\
10.898\end{array}$ & $\begin{array}{l}8.473 \\
8.630 \\
8.558\end{array}$ & & $\begin{array}{l}0.687 \\
9.551 \\
0.809\end{array}$ & $\begin{array}{l}9.508 \\
9.647 \\
9.577\end{array}$ & $\begin{array}{l}10.303 \\
10.438 \\
10.379\end{array}$ \\
\hline $\begin{array}{l}\text { CVS2.7.2. } \\
\text { CVS2.7 } \\
\text { AVERAGE }\end{array}$ & $\begin{array}{l}200062212 \\
200062213\end{array}$ & $\begin{array}{l}9.90 \\
9.80 \\
8.80\end{array}$ & $\begin{array}{l}5.340 \\
5.358 \\
5.353\end{array}$ & $\begin{array}{l}9.178 \\
9.013 \\
9.005\end{array}$ & & $\begin{array}{l}25.752 \\
25.286 \\
25.518\end{array}$ & $\begin{array}{l}27.414 \\
28.393 \\
28.904\end{array}$ & $\begin{array}{l}4.495 \\
4.400 \\
4.482\end{array}$ \\
\hline $\begin{array}{l}\text { CVS2-18-28-1 } \\
\text { CVS2-18-28-2 } \\
\text { AVERABE }\end{array}$ & $\begin{array}{l}200062214 \\
200062215\end{array}$ & $\begin{array}{l}9.50 \\
9.50 \\
9.55\end{array}$ & $\begin{array}{l}15.855 \\
16.540 \\
16.197\end{array}$ & $\begin{array}{l}13.706 \\
14.292 \\
14.044\end{array}$ & & $\begin{array}{l}16.702 \\
17.540 \\
17.121\end{array}$ & $\begin{array}{l}17.478 \\
18.468 \\
17.973\end{array}$ & $\begin{array}{l}16.421 \\
17.149 \\
16.785\end{array}$ \\
\hline $\begin{array}{l}\text { CVS2.17.28.1 } \\
\text { CVS2.17.28.2 } \\
\text { AVERASE }\end{array}$ & $\begin{array}{l}200062216 \\
200062297\end{array}$ & $\begin{array}{l}9.46 \\
9.42 \\
9.44\end{array}$ & $\begin{array}{l}14.898 \\
14.865 \\
14.881\end{array}$ & $\begin{array}{l}10.033 \\
10.74 \\
10.104\end{array}$ & & $\begin{array}{l}13.327 \\
13.260 \\
13.298\end{array}$ & $\begin{array}{l}14.184 \\
14.308 \\
14.248\end{array}$ & $\begin{array}{l}12.811 \\
12.811 \\
12.911\end{array}$ \\
\hline $\begin{array}{l}\text { CVS.18.28.1 } \\
\text { CVS.18.28.2 } \\
\text { AVERAGE }\end{array}$ & $\begin{array}{l}200082218 \\
200062210\end{array}$ & $\begin{array}{l}9.59 \\
9.59 \\
9.59\end{array}$ & $\begin{array}{l}16.983 \\
17.320 \\
17.151\end{array}$ & $\begin{array}{l}12.918 \\
13.182 \\
13.049\end{array}$ & $\begin{array}{l}6.231 \\
0.063 \\
7.647\end{array}$ & $\begin{array}{l}16.175 \\
18.400 \\
16.288\end{array}$ & $\begin{array}{l}17.338 \\
17.652 \\
17.495\end{array}$ & $\begin{array}{l}15.400 \\
15.050 \\
15.676\end{array}$ \\
\hline $\begin{array}{l}\text { A RM-1.28.1 } \\
\text { A RM-1.28.2 } \\
\text { AVERMEE }\end{array}$ & $\begin{array}{l}200062220 \\
200062221\end{array}$ & $\begin{array}{l}9.55 \\
9.50 \\
9.53\end{array}$ & $\begin{array}{l}13.037 \\
13.061 \\
13.049\end{array}$ & $\begin{array}{l}10.404 \\
10.205 \\
10.305\end{array}$ & & $\begin{array}{l}12.959 \\
12.838 \\
12.808\end{array}$ & $\begin{array}{l}14.229 \\
13.213 \\
13.721\end{array}$ & $\begin{array}{l}12.150 \\
12.279 \\
12.212\end{array}$ \\
\hline
\end{tabular}


Table 8. Logarithm of the MCC-1 Normalized Releases for CVS-II Glasses (Corrected for Blank Analyses)

\begin{tabular}{|c|c|c|c|c|c|c|c|c|}
\hline Sample & $\begin{array}{l}\text { ADS } \\
\text { SAMPLE }\end{array}$ & $\begin{array}{r}\text { LFACMATE } \\
\text { pH }\end{array}$ & $\begin{array}{l}100 N L i(B) \\
(g / m 2)\end{array}$ & $\begin{array}{r}100 N L I(S) \\
(0 / m 2)\end{array}$ & $\begin{array}{c}\log N L 1(K) \circ g \\
(g / m 2)\end{array}$ & $\begin{array}{c}\mathrm{NLI}(\mathrm{Na}) I C P \log \\
(\alpha / \mathrm{m} 2)\end{array}$ & $\underset{(g / m 2)}{N L I(N \&) M A}$ & $\begin{array}{l}100 N L /(L)) \\
(g / m 2)\end{array}$ \\
\hline $\begin{array}{l}\text { CVS2-5-28.1 } \\
\text { CVS2-5.28.2 } \\
\text { AVFRAGE }\end{array}$ & $\begin{array}{l}200062210 \\
200062211\end{array}$ & $\begin{array}{l}9.28 \\
9.01 \\
9.00\end{array}$ & $\begin{array}{l}1.032 \\
1.042 \\
1.037\end{array}$ & $\begin{array}{l}0.928 \\
0.936 \\
0.932\end{array}$ & & $\begin{array}{l}0.985 \\
0.980 \\
0.983\end{array}$ & $\begin{array}{l}0.978 \\
0.981 \\
0.981\end{array}$ & $\begin{array}{l}8.013 \\
1.010 \\
1.018\end{array}$ \\
\hline $\begin{array}{l}\text { CVS2.7-2.8.1 } \\
\text { CVS2.7.28.2 } \\
\text { AVERUGE }\end{array}$ & $\begin{array}{l}200062212 \\
200062213\end{array}$ & $\begin{array}{l}9.90 \\
9.90 \\
9.90\end{array}$ & $\begin{array}{l}0.720 \\
0.729 \\
0.729\end{array}$ & $\begin{array}{l}0.963 \\
0.955 \\
0.958\end{array}$ & & $\begin{array}{l}1.411 \\
1.403 \\
1.407\end{array}$ & $\begin{array}{l}1.438 \\
1.421 \\
1.430\end{array}$ & $\begin{array}{l}0.653 \\
0.044 \\
0.640\end{array}$ \\
\hline $\begin{array}{l}\text { CVS2.16.28. } \\
\text { CVS2.16.28. } \\
\text { AVERMEE }\end{array}$ & $\begin{array}{l}200062214 \\
200062215\end{array}$ & $\begin{array}{l}9.59 \\
9.50 \\
9.55\end{array}$ & $\begin{array}{l}1.200 \\
1.210 \\
1.200\end{array}$ & $\begin{array}{l}1.140 \\
1.155 \\
1.147\end{array}$ & & $\begin{array}{l}1.223 \\
1.244 \\
1.234\end{array}$ & $\begin{array}{l}1.242 \\
1.286 \\
1.256\end{array}$ & $\begin{array}{l}1.218 \\
1.234 \\
1.228\end{array}$ \\
\hline $\begin{array}{l}\text { CVS2.17.28. } \\
\text { CVS2.17.28. } \\
\text { AVERAGE }\end{array}$ & $\begin{array}{l}200062216 \\
200062217\end{array}$ & $\begin{array}{l}0.46 \\
8.42 \\
9.44\end{array}$ & $\begin{array}{l}1.173 \\
1.172 \\
1.173\end{array}$ & $\begin{array}{l}1.001 \\
1.007 \\
1.004\end{array}$ & & $\begin{array}{l}1.125 \\
1.123 \\
1.124\end{array}$ & $\begin{array}{l}1.152 \\
1.150 \\
1.154\end{array}$ & $\begin{array}{l}1.111 \\
1.111 \\
1.111\end{array}$ \\
\hline $\begin{array}{l}\text { CVS.18.28.1 } \\
\text { CVS.18.28.2 } \\
\text { AVERVEE }\end{array}$ & $\begin{array}{l}200082218 \\
200082219\end{array}$ & $\begin{array}{l}9.59 \\
9.59 \\
9.50\end{array}$ & $\begin{array}{l}1.230 \\
1.230 \\
1.234\end{array}$ & $\begin{array}{l}1.111 \\
1.120 \\
1.116\end{array}$ & $\begin{array}{l}0.705 \\
0.857 \\
0.883\end{array}$ & $\begin{array}{l}1.200 \\
1.215 \\
1.212\end{array}$ & $\begin{array}{l}1.230 \\
1.247 \\
1.243\end{array}$ & $\begin{array}{l}1.100 \\
1.200 \\
1.196\end{array}$ \\
\hline $\begin{array}{l}\text { ARM.1.28.1 } \\
\text { ARM-1.28.2 } \\
\text { AVERAGE }\end{array}$ & $\begin{array}{l}200062220 \\
200062221\end{array}$ & $\begin{array}{l}9.55 \\
9.50 \\
9.53\end{array}$ & $\begin{array}{l}1.115 \\
1.116 \\
1.118\end{array}$ & $\begin{array}{l}1.017 \\
1.009 \\
1.013\end{array}$ & & $\begin{array}{l}1.113 \\
1.108 \\
1.111\end{array}$ & $\begin{array}{l}1.153 \\
1.121 \\
1.137\end{array}$ & $\begin{array}{l}1.088 \\
1.089 \\
1.007\end{array}$ \\
\hline
\end{tabular}

Notobcok DPSTN-4507 (E.48203) 


\section{X-RAX ANALYSIS AND SCANNING ELECTRON MUCROSCOPY}

Rutheniur: dioxide was identified in all the CVS-II glasses by X-ray diffraction analysis (Table 9). In CVS-16 and CVS-17 small amounts of irregularly distributed $\mathrm{Cu}-\mathrm{Ni}$ alloy were detecter during SEM/EDAX analysis. In CVS-5 and CVS-17 a Ca-Zr-Al-Fe silicate containing La and Na or two phases (a Ca-Zr-Al-Fe silicate and a rare earth oxide) were detected. In CVS-5 there was sufficient amounts of this phase to yield a strong $\mathrm{x}$-ray diffraction pattern. However, positive phase identification was not possible from the complex pattern. In CVS-18 a mixed chloride phase, $(\mathrm{Na}, \mathrm{K}) \mathrm{Cl}$, was observed.

During SEM analysis it was noted that all of the surfaces of a crushed grain did not have the same surface texture. Many grains had one dull flat textured surface indicating that before grinding the samples for the PCT, the original glass specimen was not free of melt cast surfaces. Textural differences in glass surfaces can impart variation to the PCT response to a glass composition.

\section{CONCLUSIONS}

The PCT leachate data of the CVS-II glasses appears to be internally consistent except for the $\mathrm{Si}$ and $\mathrm{Na}$ analyses of the CVS2-7 glass. No long term or short term instrumental analytic bias was observed. The chemical analysis of the target compositions indicate that they are approximately correct. RuO2 was detected in all of the glasses by $\mathrm{x}$-ray diffraction. Small amounts of other phases were detected during the scinning electron microscopy analysis in four out of the five glasses examined. All of the glasses exhibited irregular surface texture indicating that the original samples contained melt cast surfaces as well as fracture surfaces. 
Table 9. Crystalline Phases Identified in CVS-II Glasses

$\begin{array}{lll}\text { Glass } & \begin{array}{l}\text { Phases Identified } \\ \text { bV XRD }\end{array} & \begin{array}{l}\text { Phases Identified } \\ \text { bV SEM }\end{array} \\ \text { CVS-5 } & \mathrm{RuO}_{2}+\text { Unknown } & \mathrm{RhO}_{2}+\mathrm{Ca}-\mathrm{Zr}-\mathrm{Al}-\mathrm{Fe} \text { silicate }+\mathrm{RE} \text { oxide } \\ \mathrm{CVS}-7 & \mathrm{RuO}_{2} & \mathrm{None} \\ \mathrm{CVS}-16 & \mathrm{RuO}_{2} & \mathrm{RuO}_{2}+\mathrm{Cu}-\mathrm{Ni} \text { alloy } \\ \mathrm{CVS}-17 & \mathrm{RuC}_{2} & \begin{array}{l}\mathrm{Cu}-\mathrm{Ni} \text { alloy }+\mathrm{Ca}-\mathrm{Zr}-\mathrm{Al}-\mathrm{Fe} \text { silicate }+\mathrm{RE} \\ \text { oxide }\end{array} \\ \mathrm{CVS}-18 & \mathrm{RuO}_{2} & \mathrm{RuO}+(\mathrm{Na}, \mathrm{K}) \mathrm{Cl}\end{array}$




\section{BEFERENCES}

1. Waste Acceptance Preliminary Specifications for the Defense Waste Processing Facility High-Level Waste Form, U. S. Department of Energy, Office of Civilian Radioactive Waste Management, USDOE Document OGR/B-8, Washington, DC (1988).

2. C. M. Jantzen and N. E. Bibler, "Product Consistency Test (PCT) and Test Protocol," USDOE Report DPST-87-575, Savannah River Laboratory, Aiken, SC (1987).

3. C. M. Jantzen and N. E. Bibler, "Nuclear Waste Product Consistency Test (PCT) -Version 3.0," WSRC-TR-90-539, Rev. 1 (November, 1990).

4. C. M. Jantzen and N. E. Bibler, "Product Consistency Test (PCT) and Test Protocol," USDOE Report DPST-87-575, Savannah River Laboratory, Aiken, SC (1987).

5. G. F. Piepel, T. E. Jones, D. L. Eggett, G. B. Mellinger, "Product Consistency Test Round Robin Conducted by the Materials Characterization Center Summary Report," USDOE Report PNL-6967, Materials Characterization Center, Battelle Pacific Northwest Laboratories, Richland, WA (1989).

б. $\quad$ N. E. Bibler and J. K. Bates, "Product Consistency Leach Tests of Savannah River Site Radioactive Waste Glasses," Scientific Basis for Nuclear Waste Management, XIII, V. M. Oversby and P. W. Brown (Eds.), Materials Research Society, Pittsburgh, PA, 327-338 (1990).

7. U.S. Department of Energy, "Environmental Assessment Waste Form Selection for SRP High-Level Waste," U.S. DOE Report DOE-EA-0179 (July, 1982).

8. C.J. Coleman, "DWPF Analytical Procedures," DPST-88-270 (March 21, 1988). 
This page intentionally left blank

$-24$ 
Appendix I

Savannah River Laboratory Glass Technology Task Control Matrix 
KEY ELEMENTS

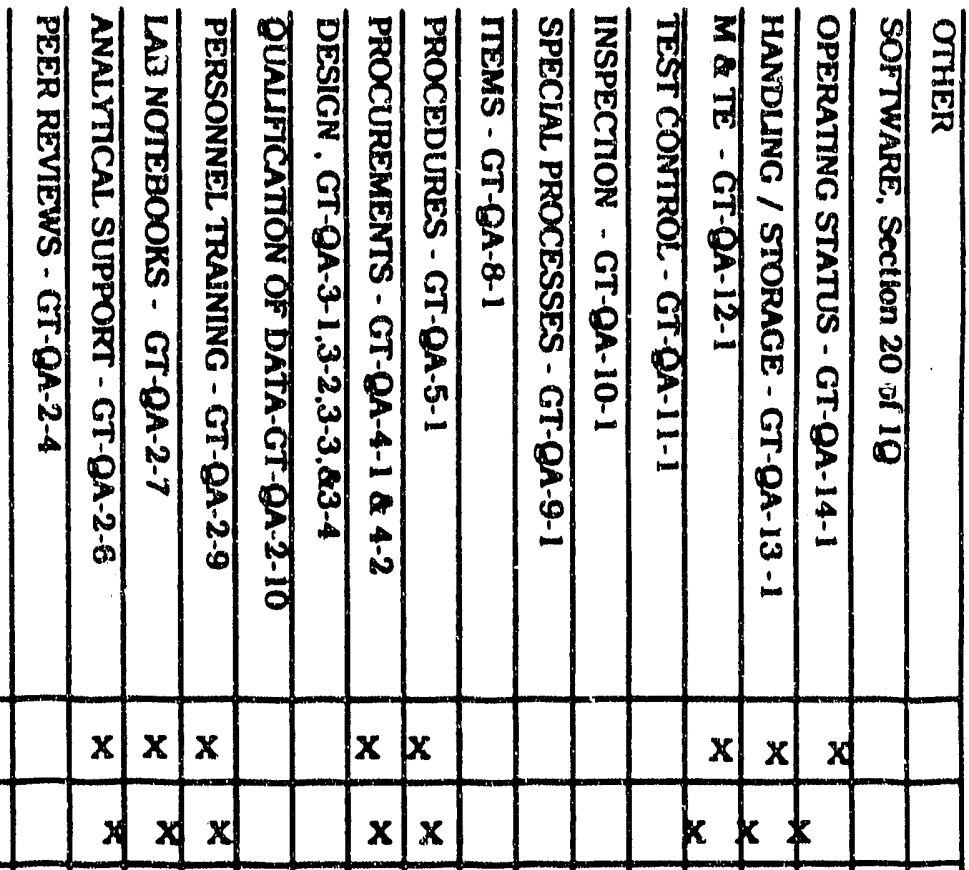

PNL-MCC-1P. TTST . REV. 1.0 $\mathbf{x} \mathbf{x}$

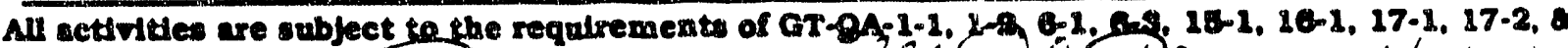

17-2.

APFROVED BY:

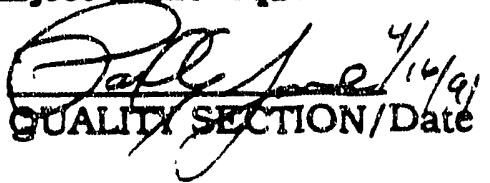

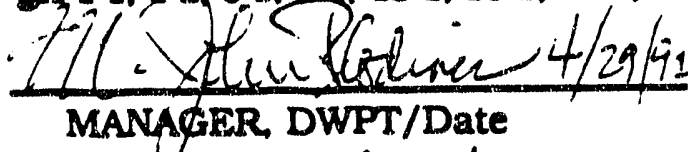
Coul kn fautzen 4/6/9/ 
Appendix II

Comparison of Targat and Analyzed Glass Composition for CVS-II Glasses 


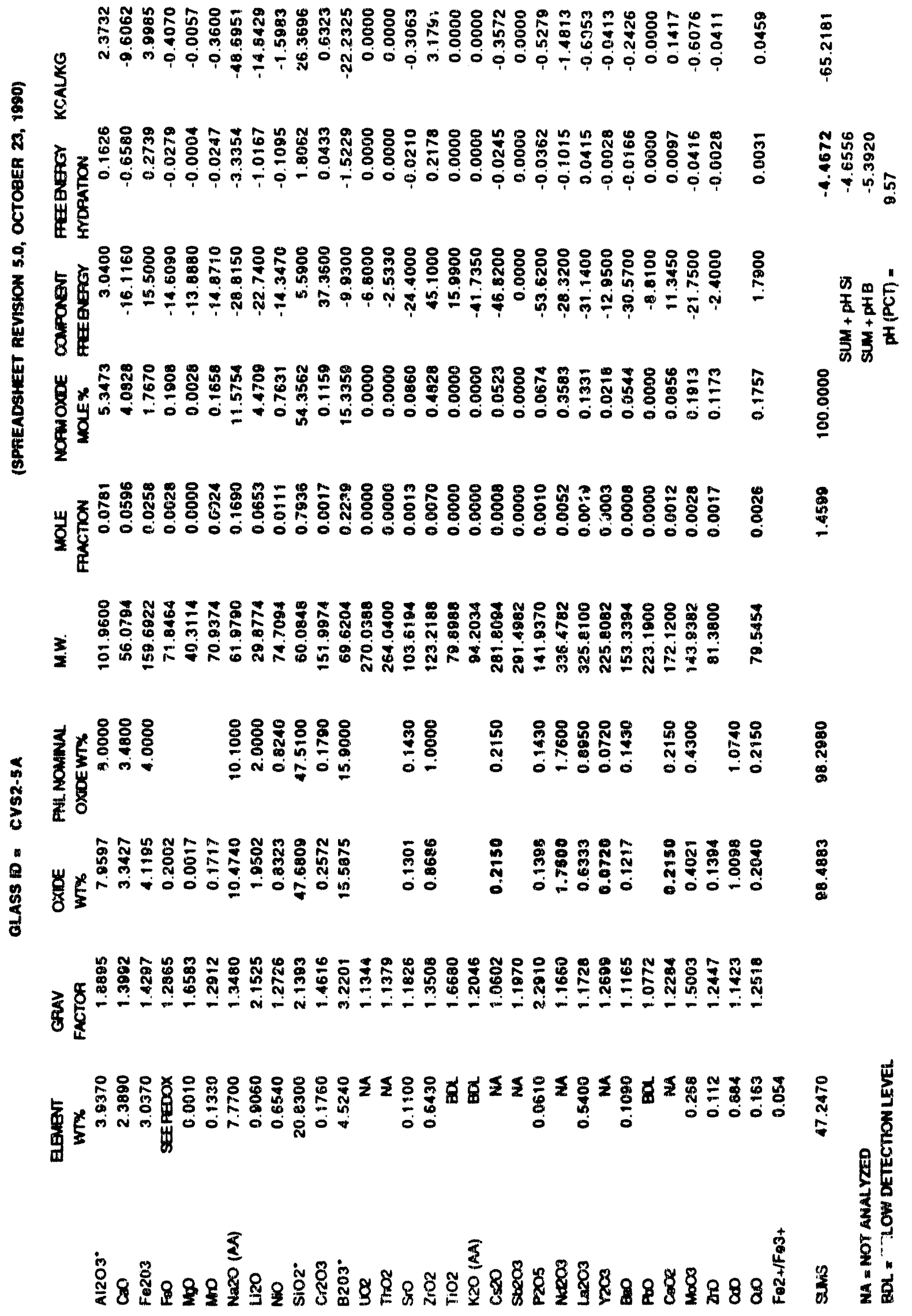




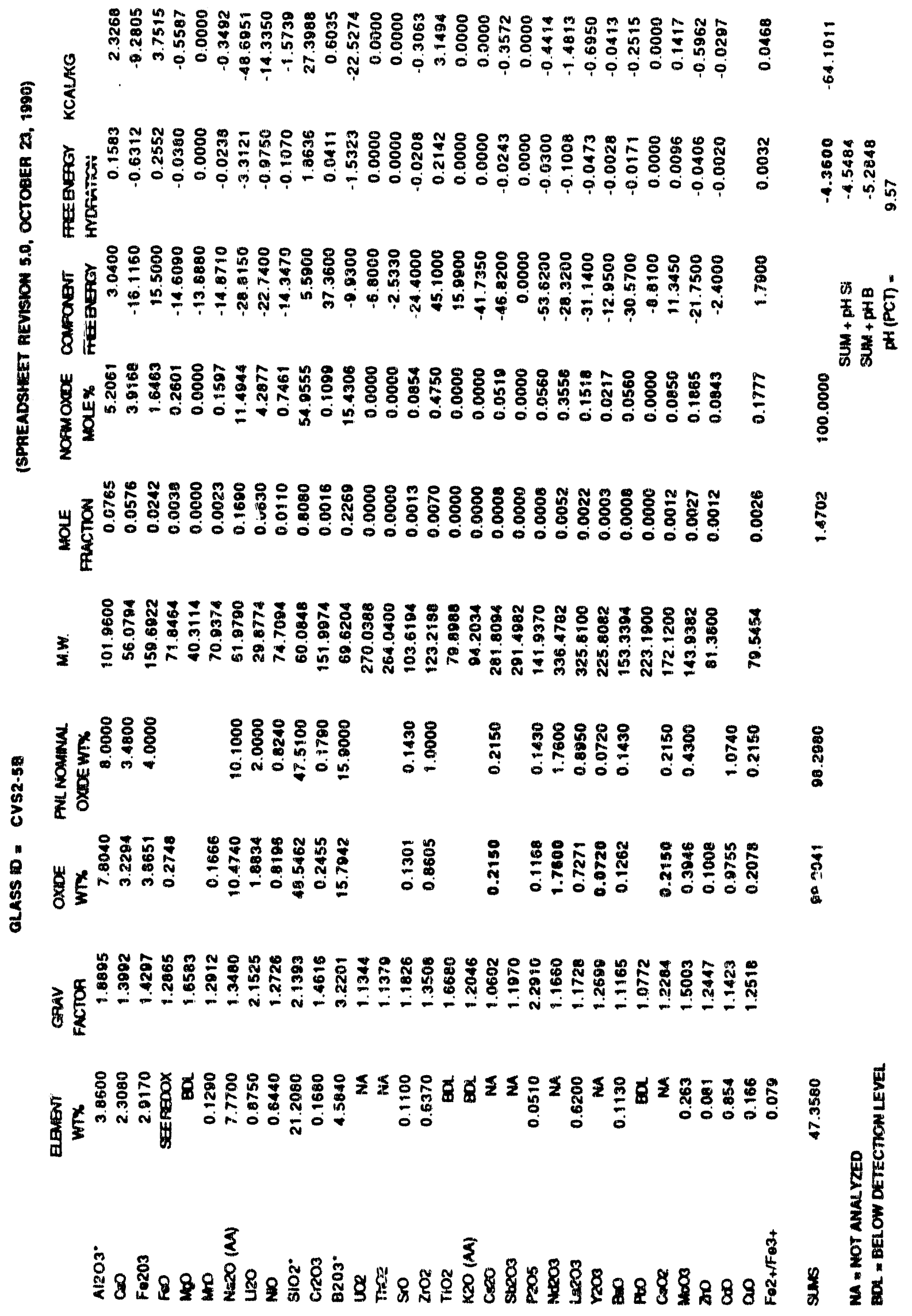




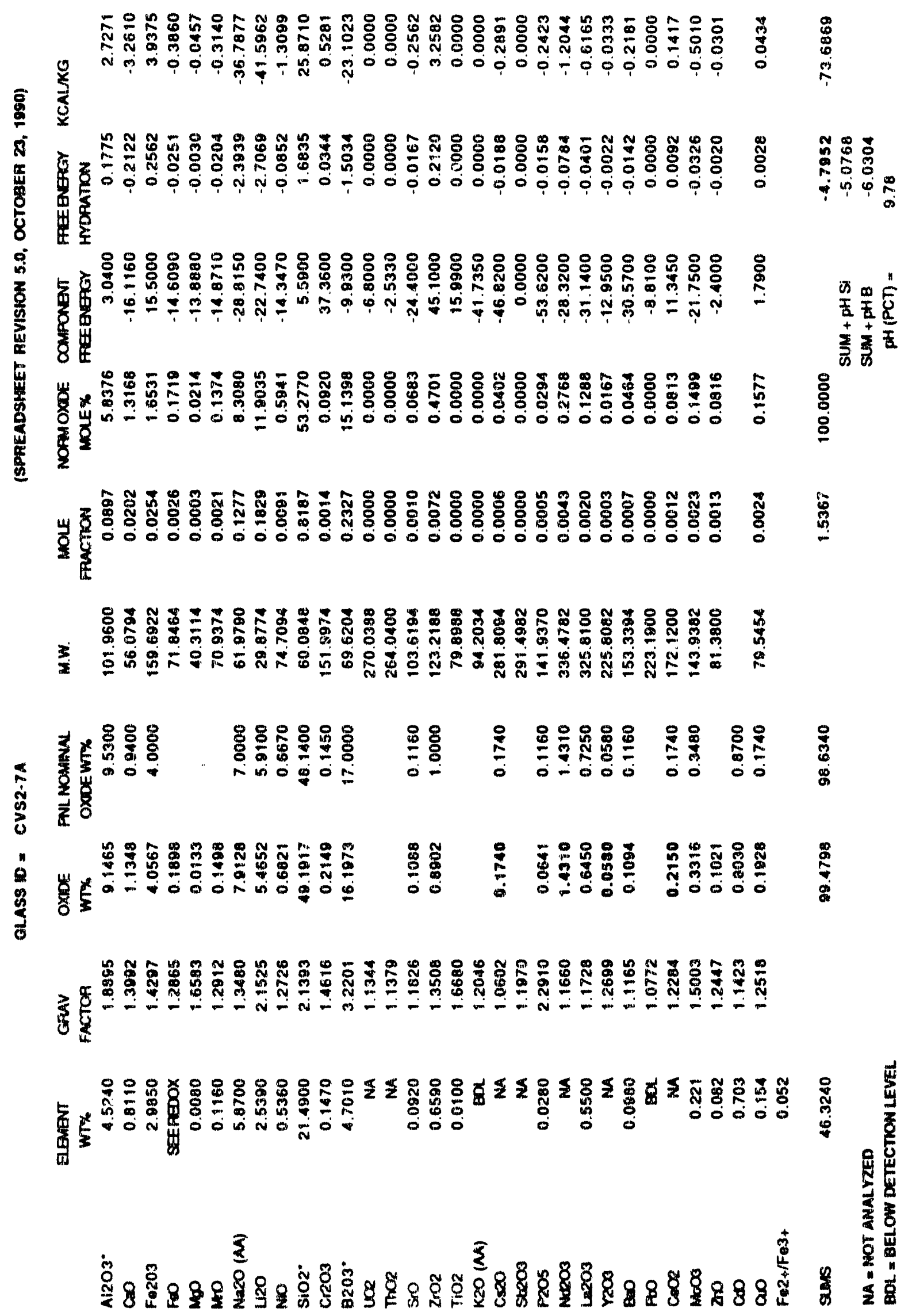




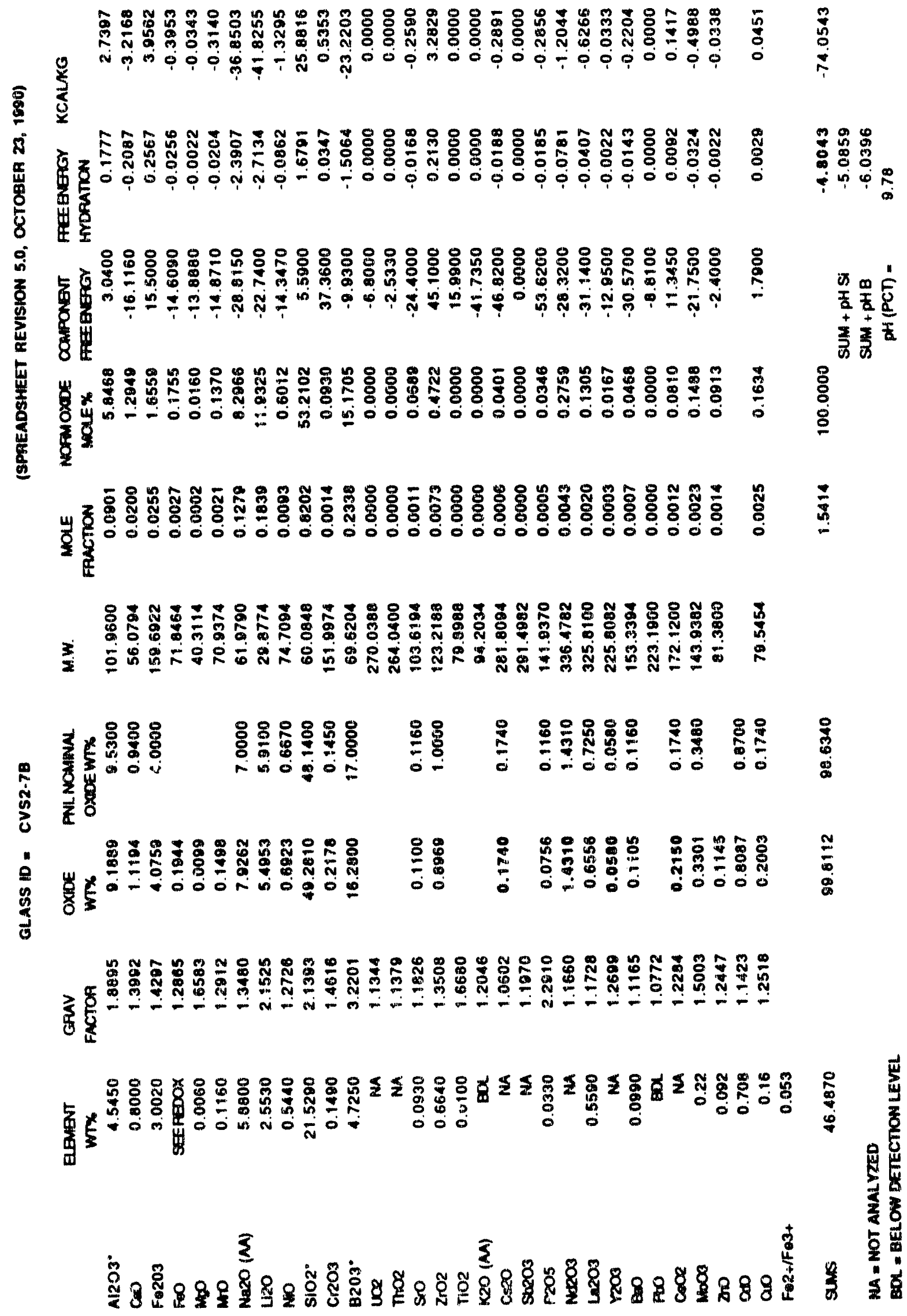




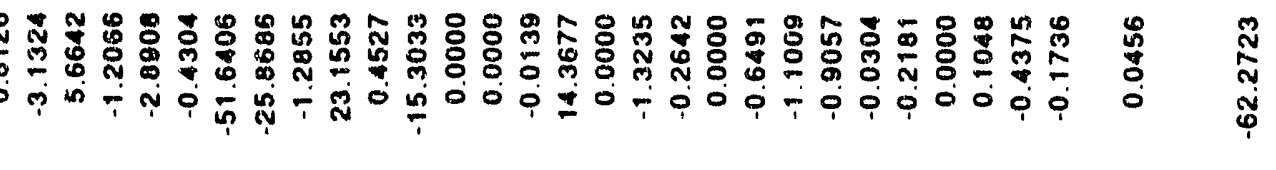

总

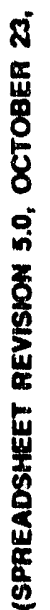

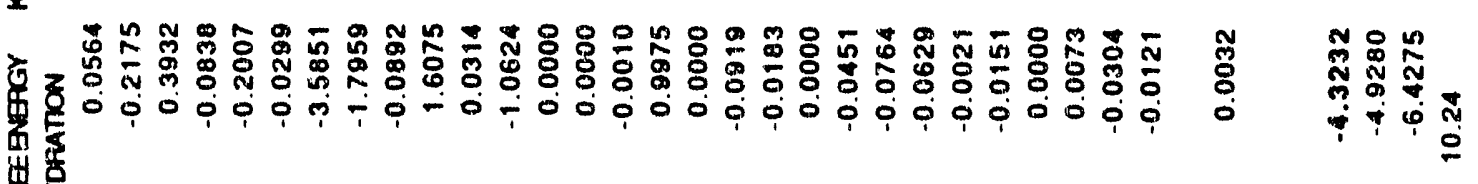

生安

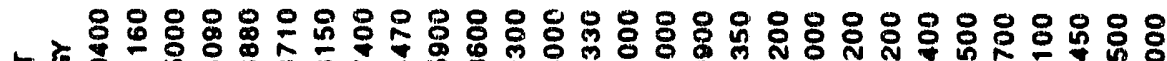

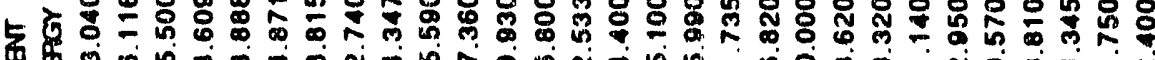

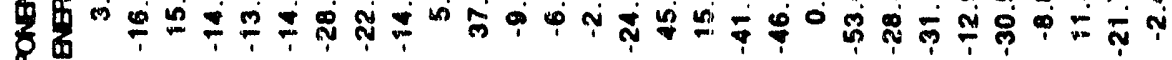

$\stackrel{8}{\stackrel{8}{2}}$

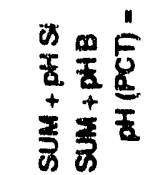

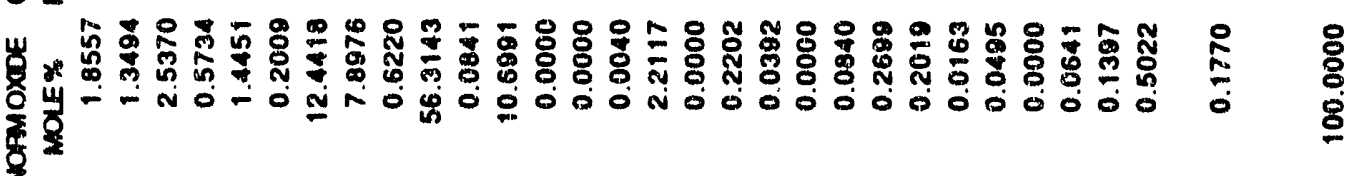

:

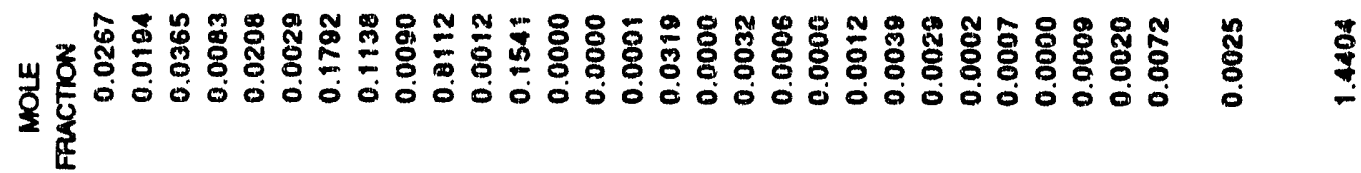

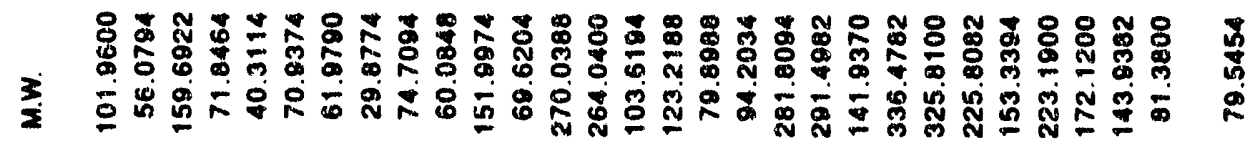

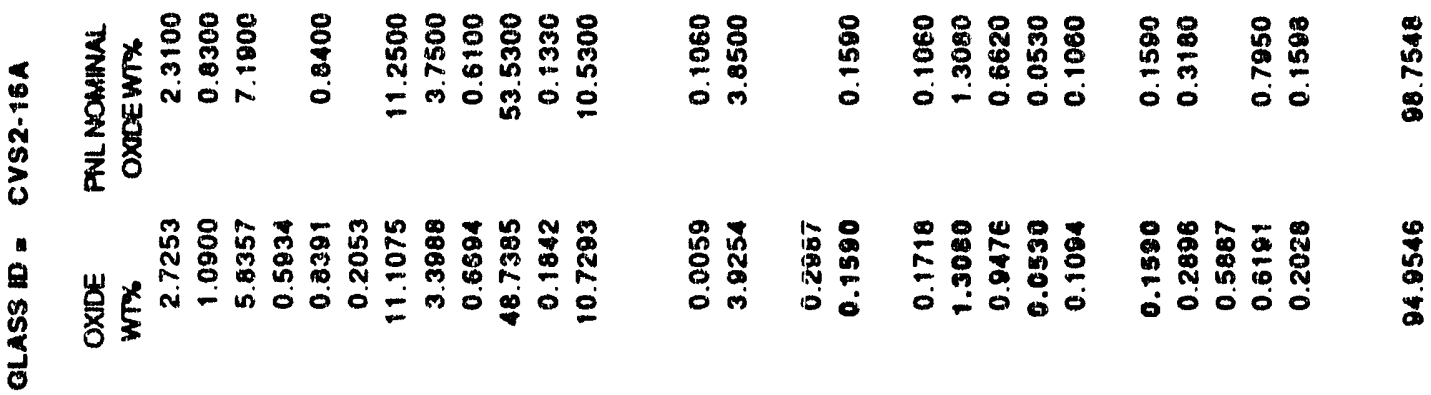

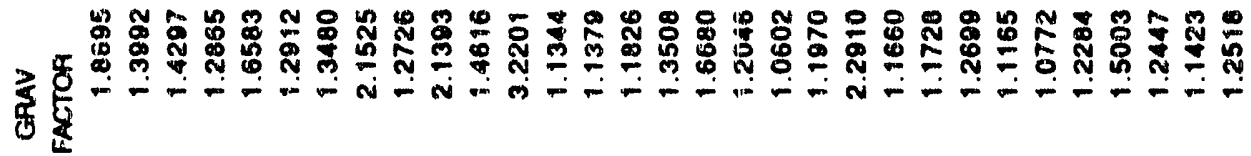

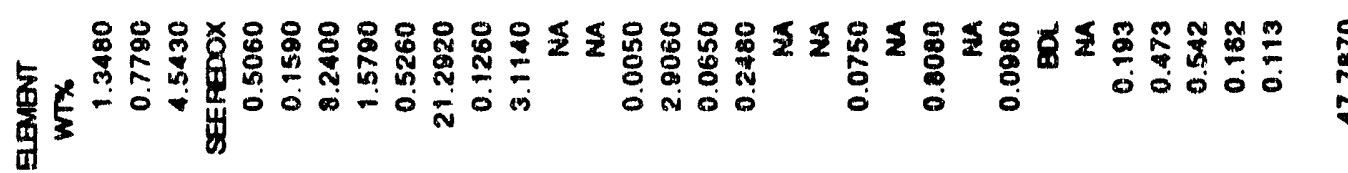

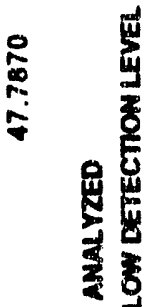

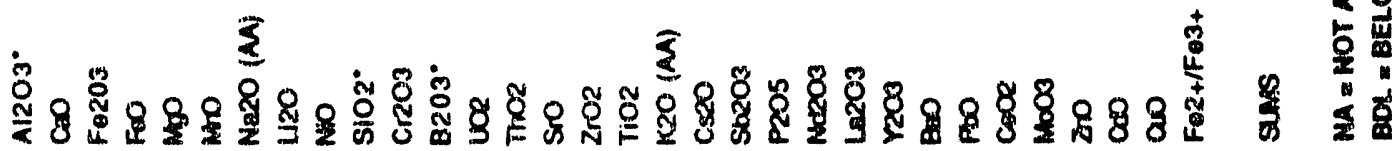




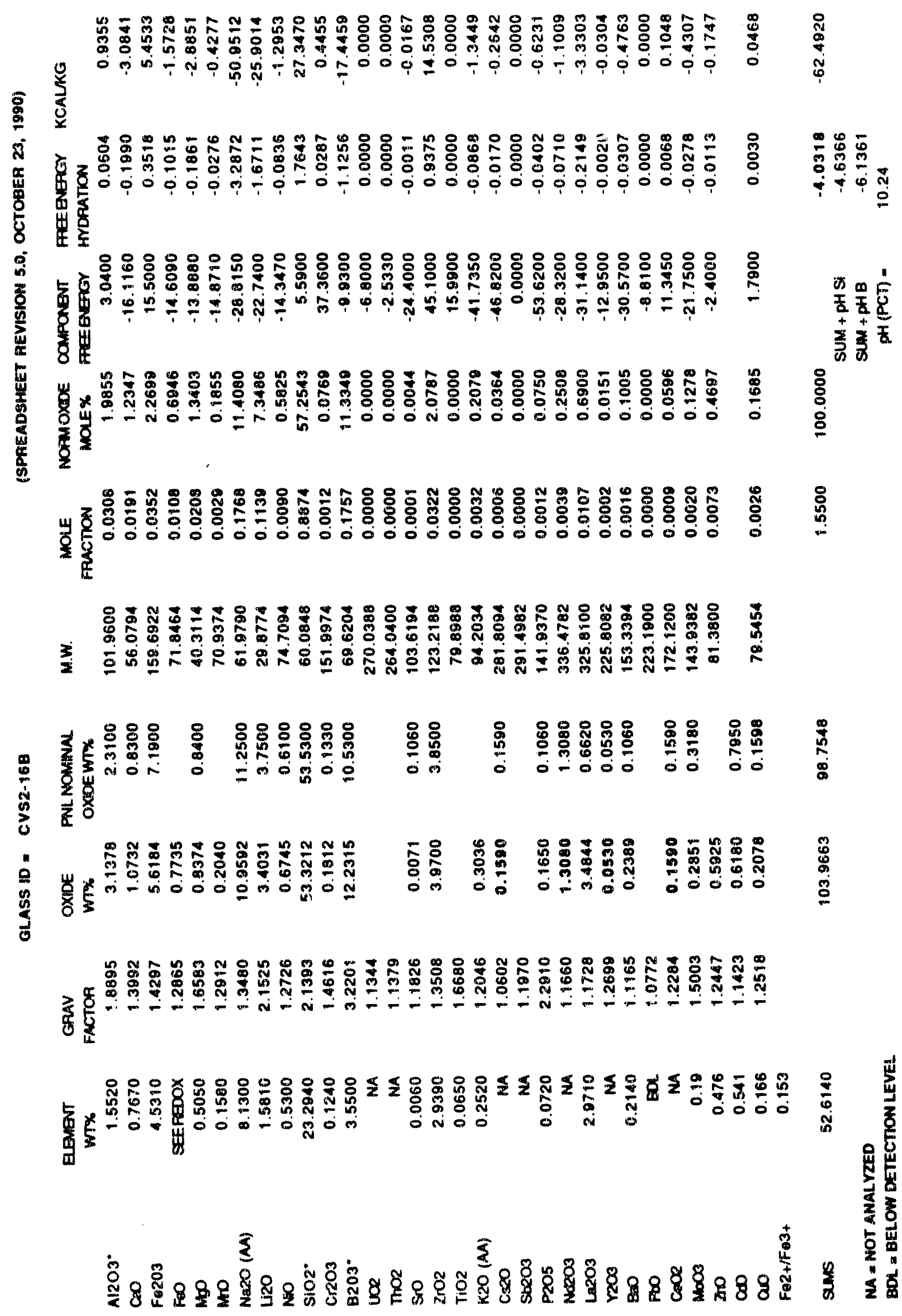




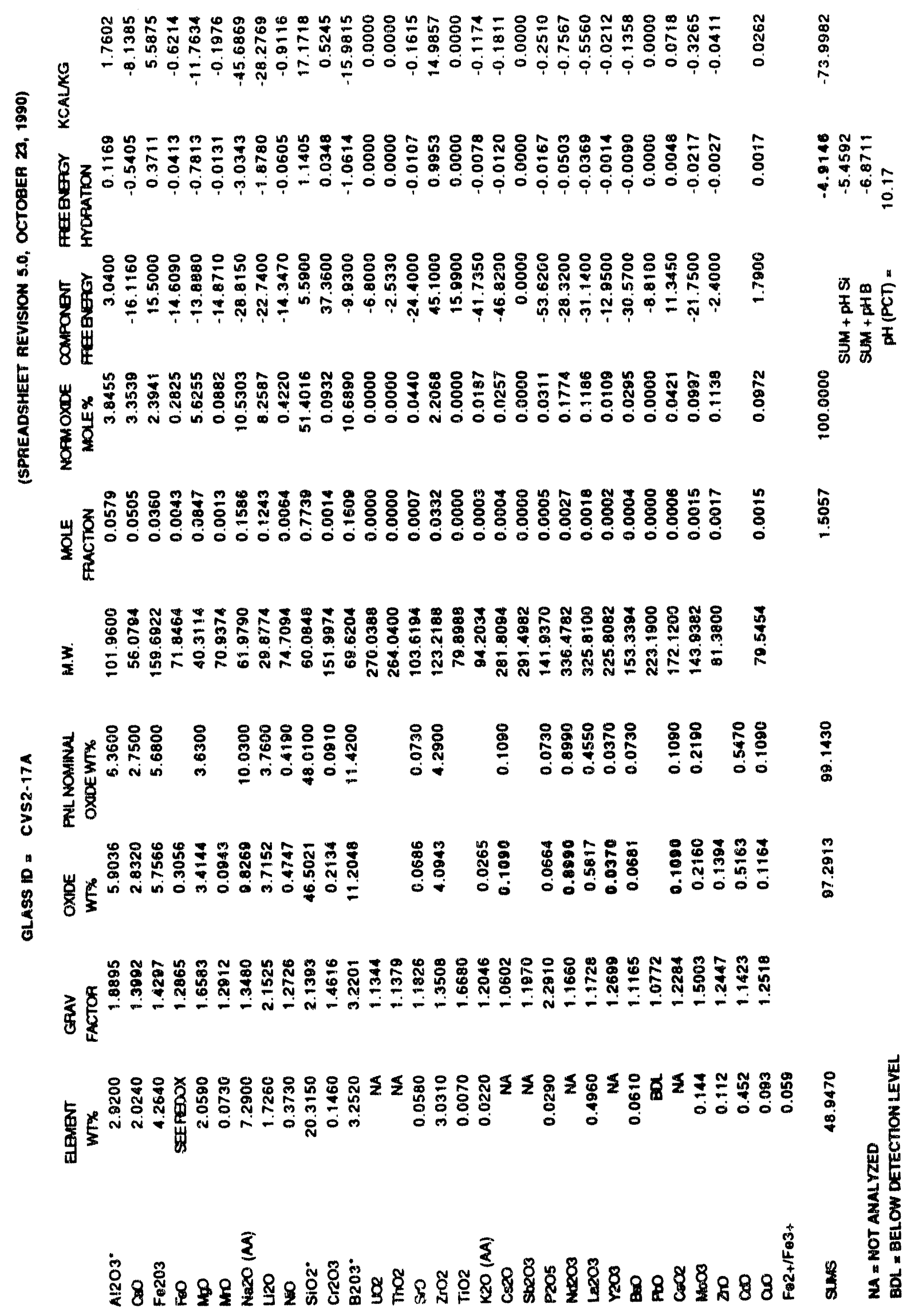




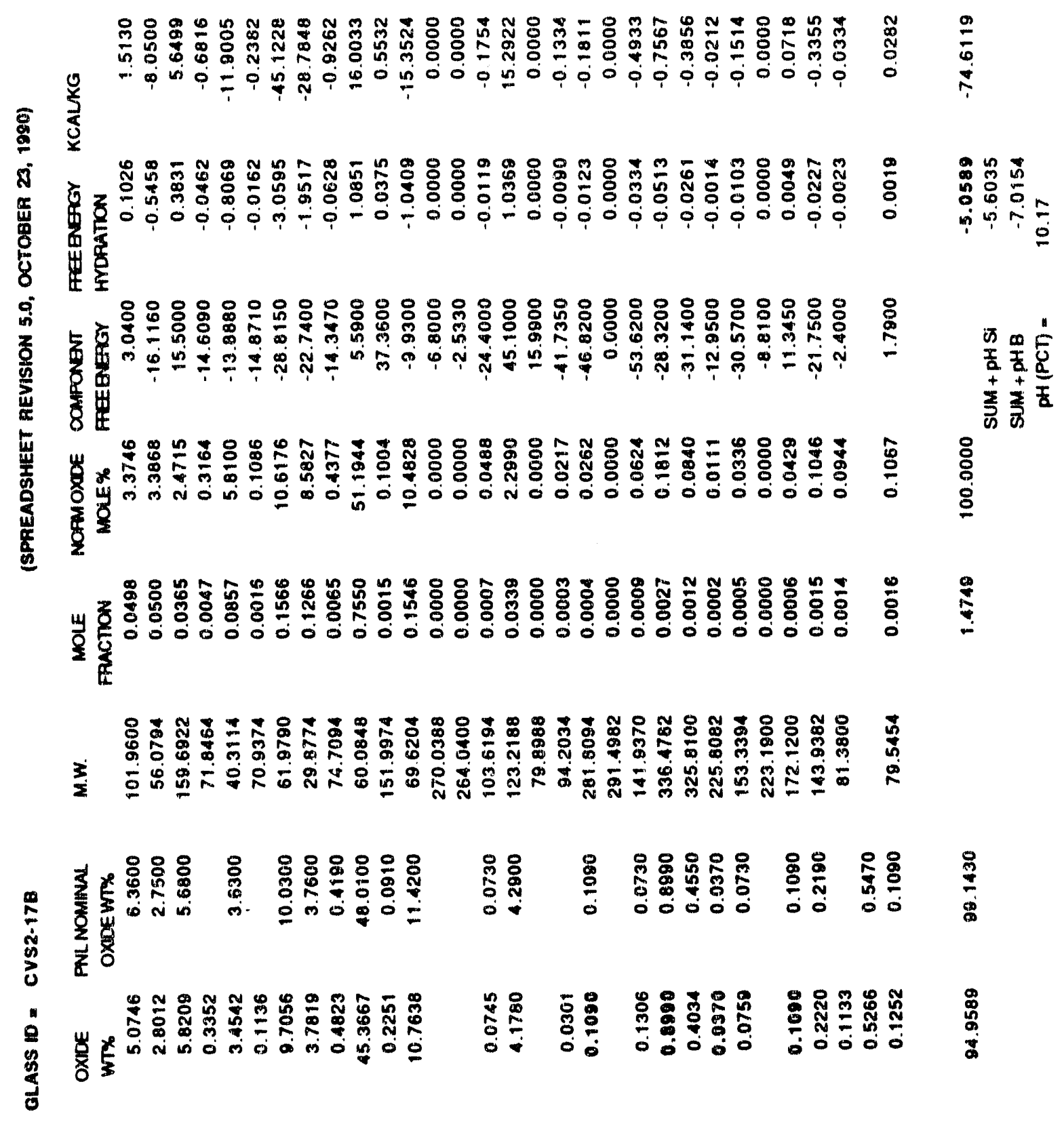

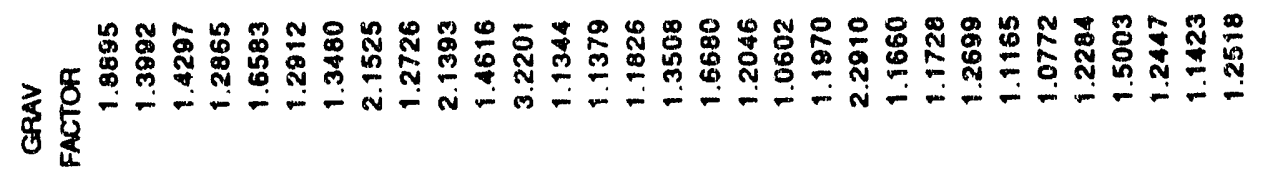

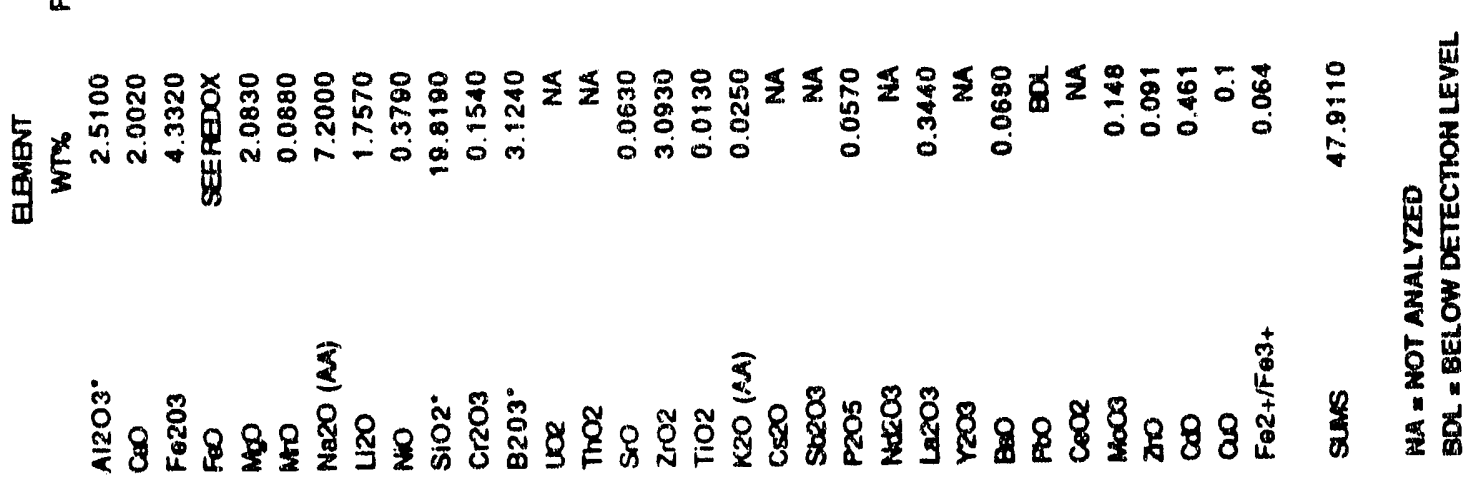

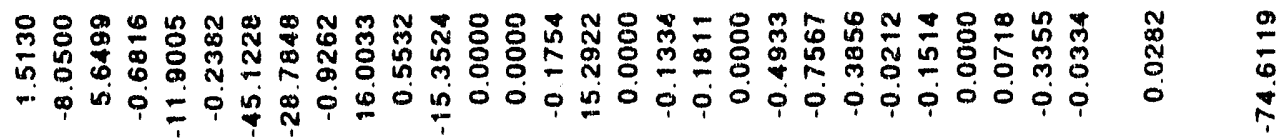

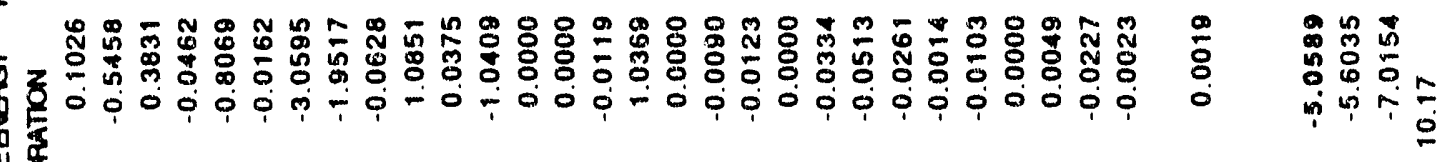

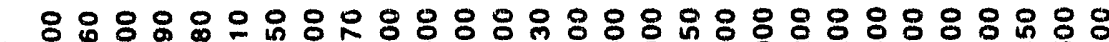

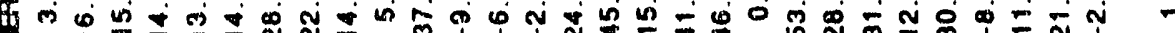
E

D =

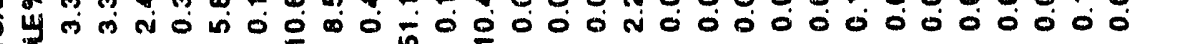

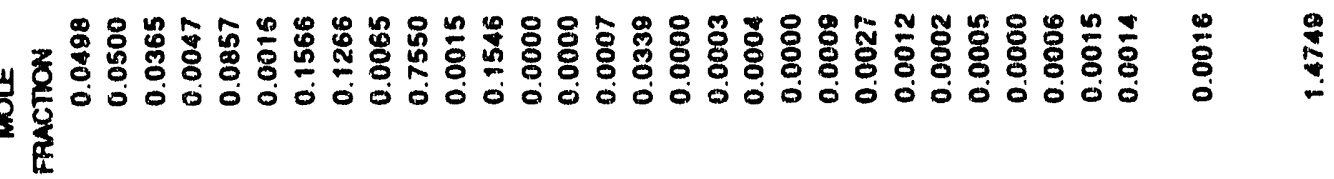

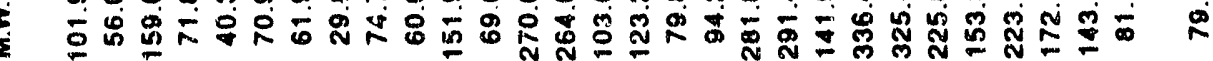




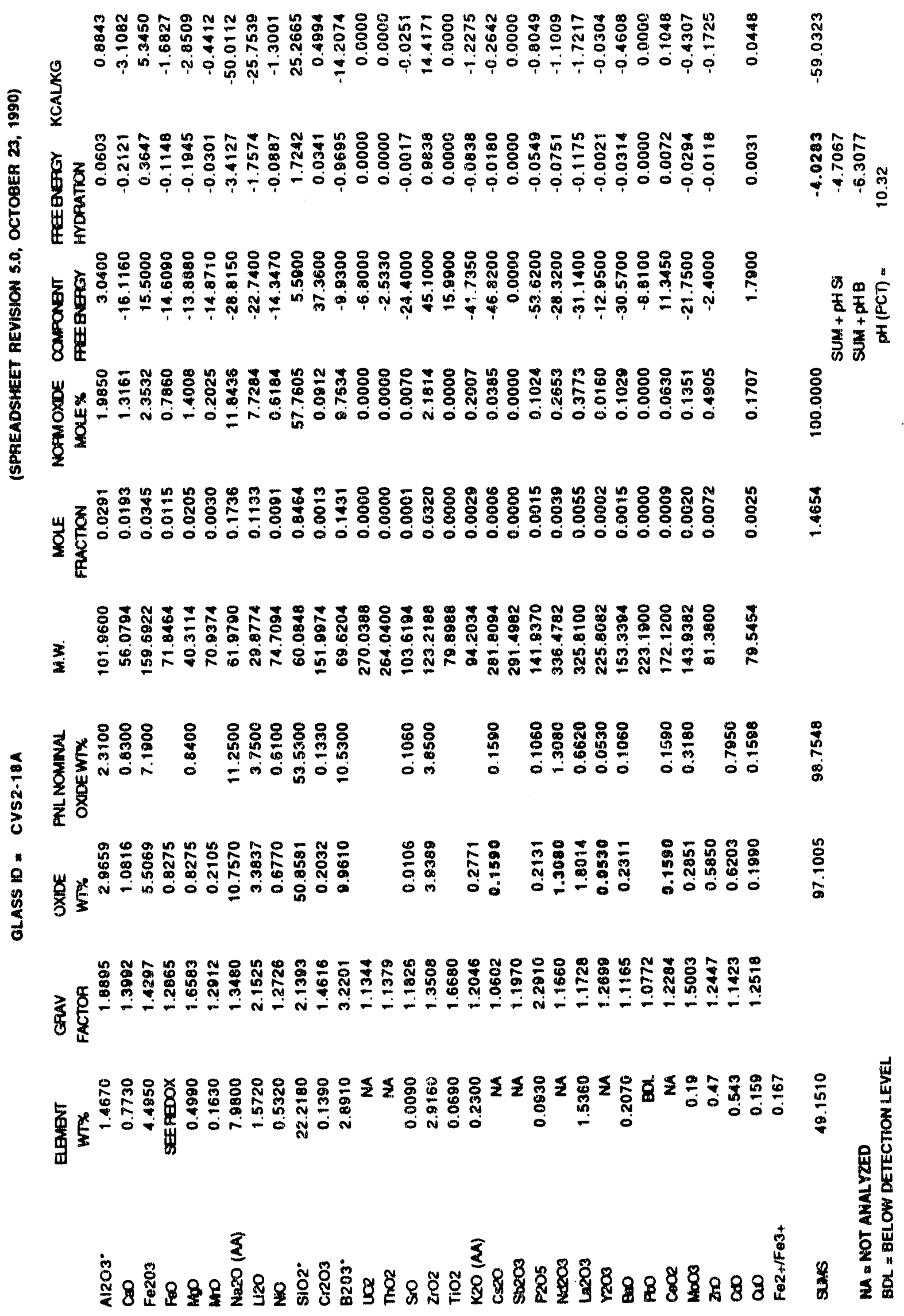




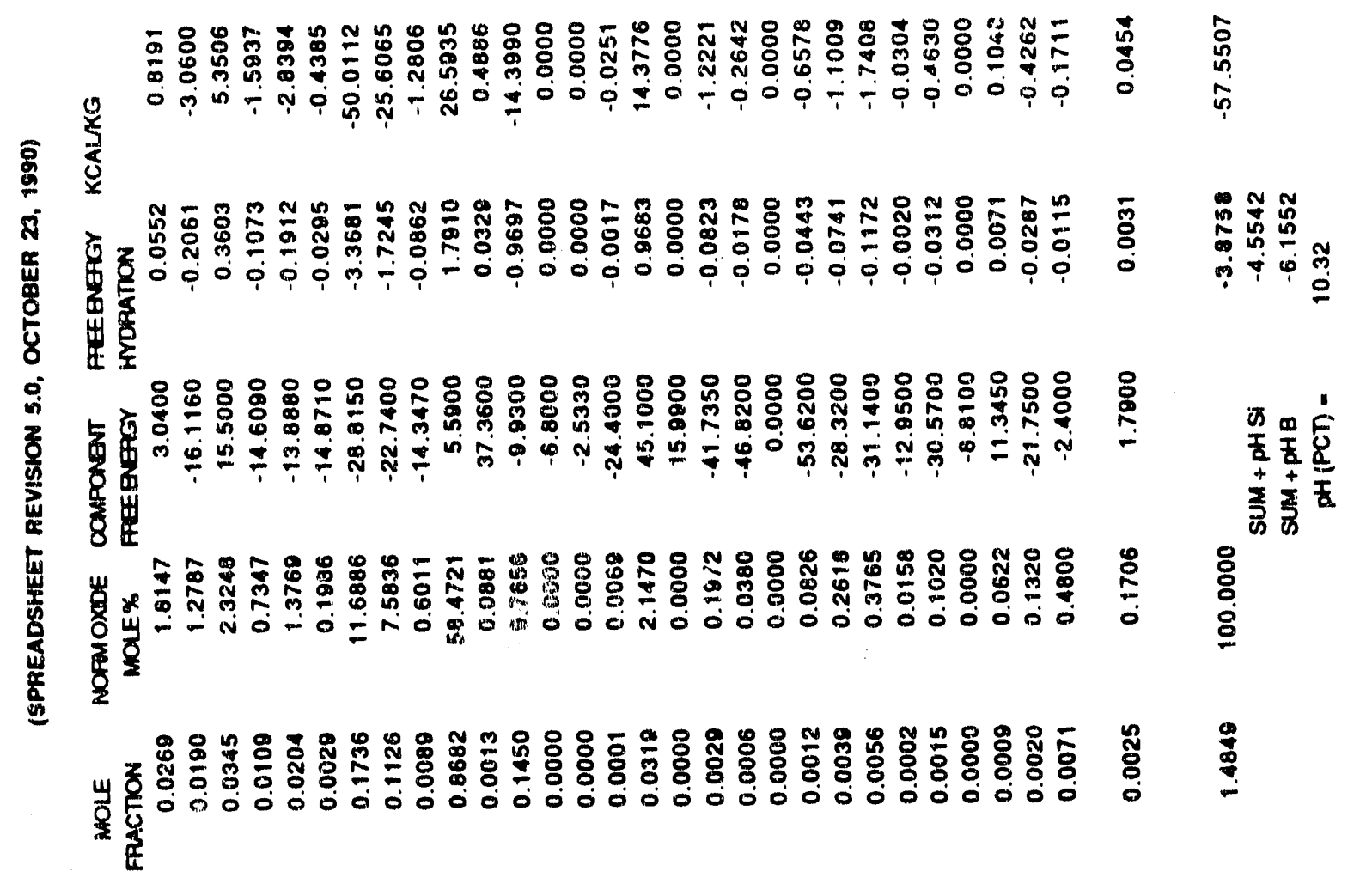

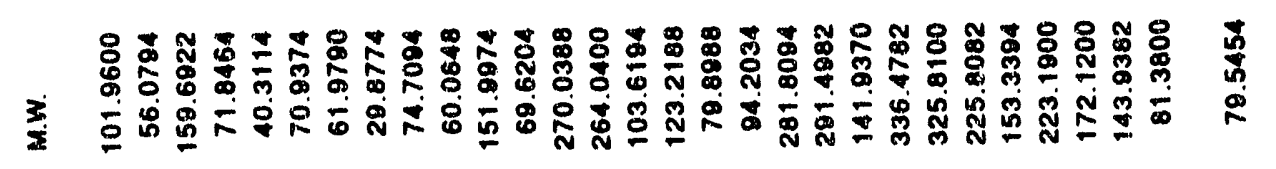

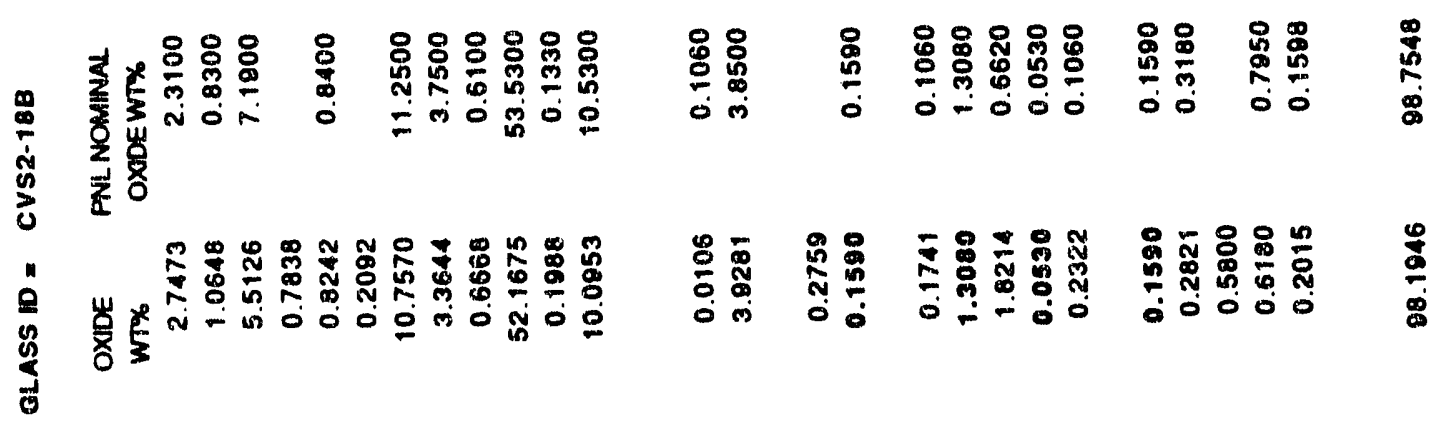

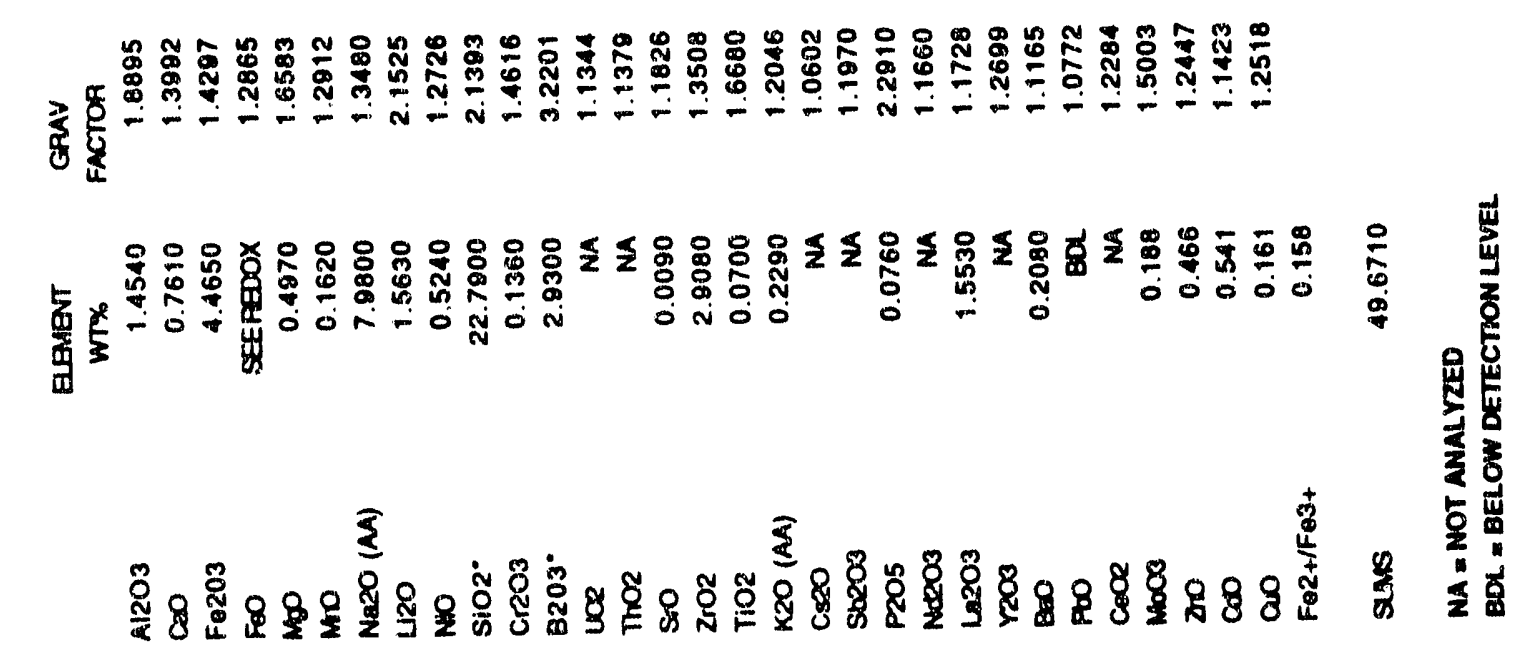




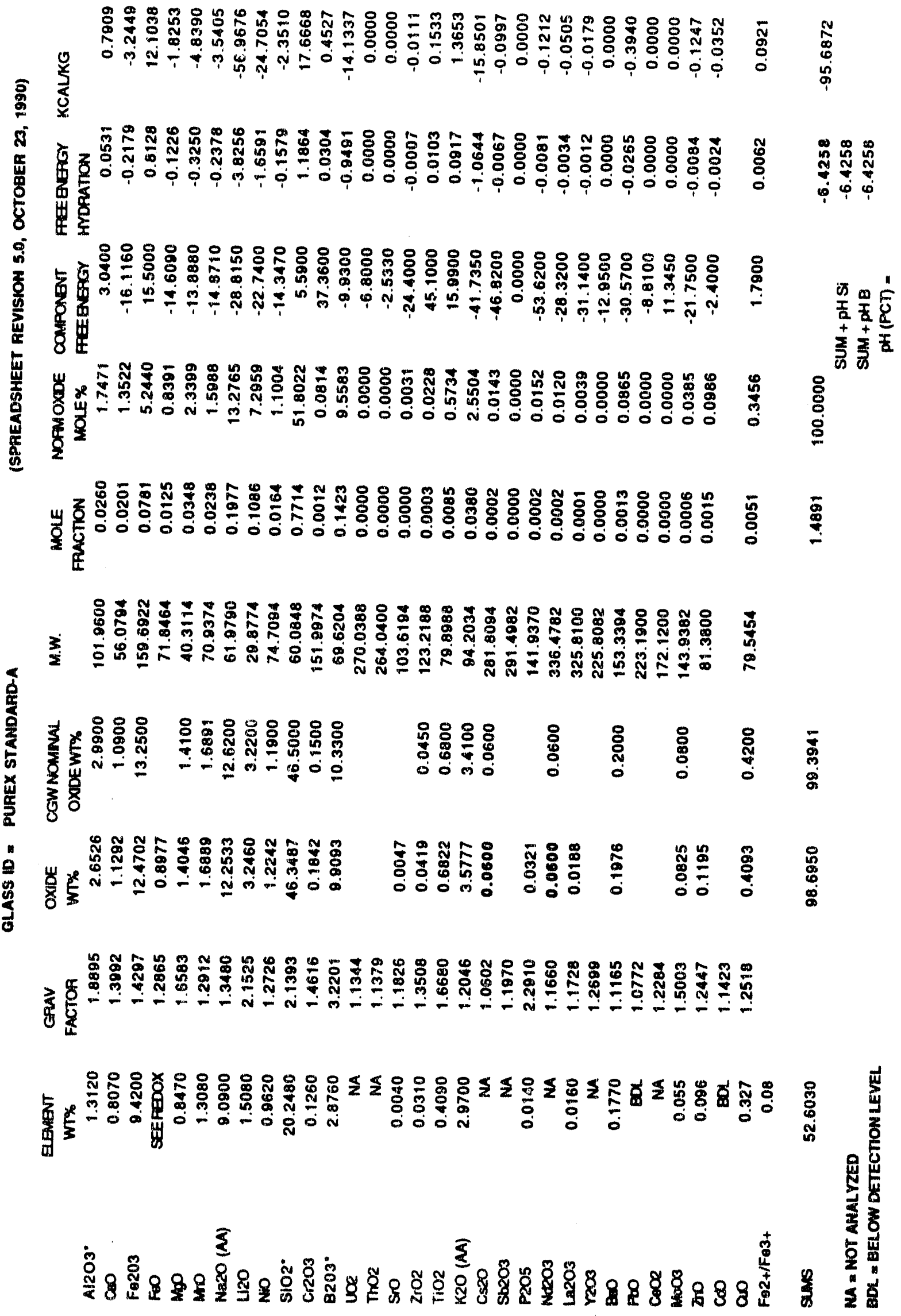




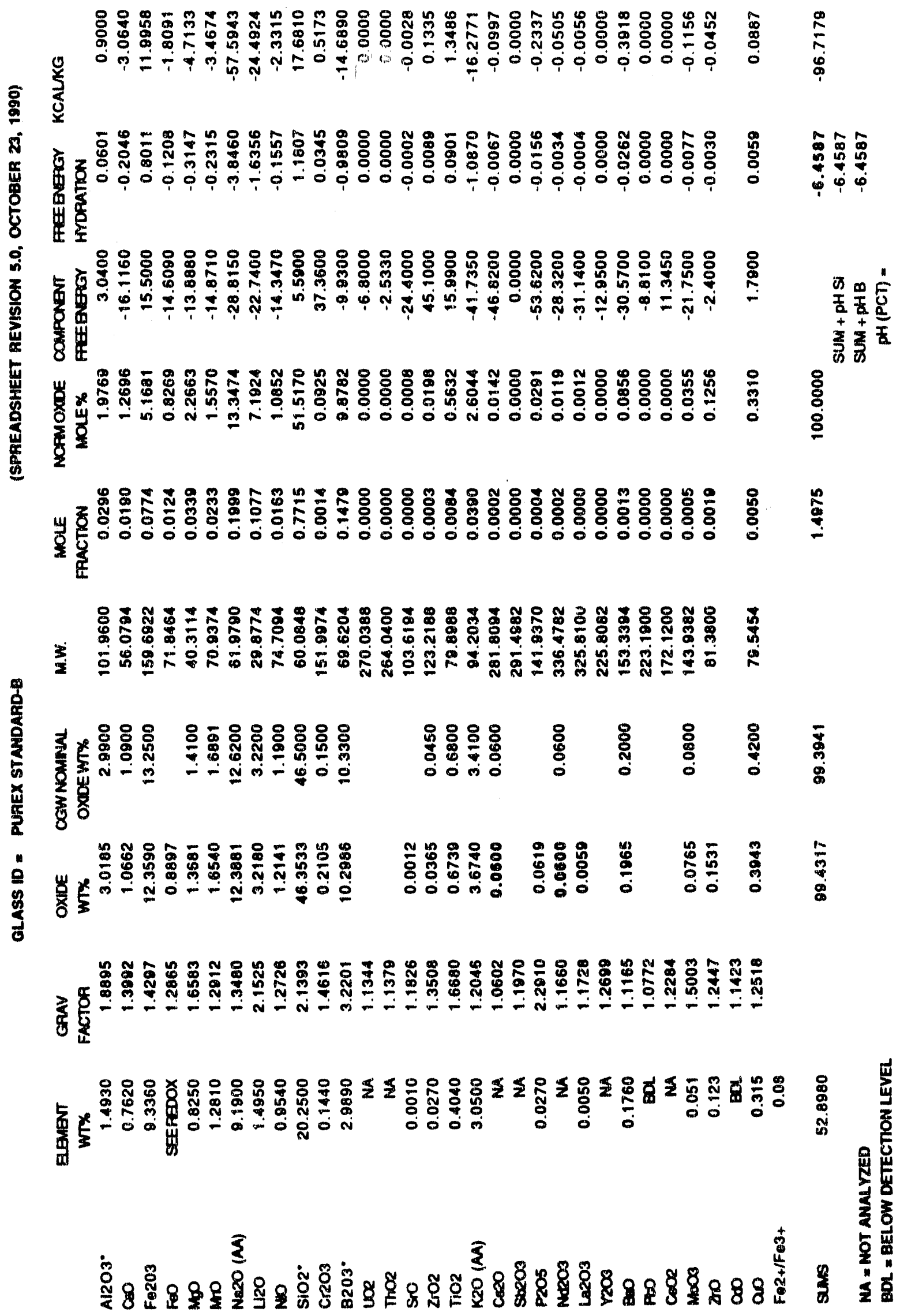


This page intentionally left blank. 
